OPEN ACCESS

Edited by:

Octavio Luiz Franco,

Universidade Católica de Brasília,

Brazi

Reviewed by

Ludmila Baltazar,

Universidade Federal de Minas

Gerais, Brazil

Camila Guimarães Freitas,

Federal Institute of Brasilia, Brazil

*Correspondence:

Eliane C. Arantes

ecabraga@fcfrp.usp.br

†These authors have contributed equally to this work

Specialty section:

This article was submitted to Antimicrobials, Resistance

and Chemotherapy,

a section of the journal

Frontiers in Microbiology

Received: 15 March 2017 Accepted: 16 May 2017

Published: 06 June 2017

Citation:

Santussi WM, Bordon KCF, Rodrigues Alves APN, Cologna CT,

Said S and Arantes EC (2017) Antifungal Activity against Filamentous Fungi of Ts1, a Multifunctional Toxin from Tityus serrulatus Scorpion Venom. Front. Microbiol. 8:984 doi: 10.3389/fmicb.2017.00984

\section{Antifungal Activity against Filamentous Fungi of Ts1, a Multifunctional Toxin from Tityus serrulatus Scorpion Venom}

\author{
Welligton M. Santussi't, Karla C. F. Bordon ${ }^{1 \dagger}$, Ana P. N. Rodrigues Alves', \\ Camila T. Cologna ${ }^{1}$, Suraia Said ${ }^{2}$ and Eliane C. Arantes ${ }^{1 *}$
}

${ }^{1}$ Laboratory of Animal Toxins, Department of Physics and Chemistry, School of Pharmaceutical Sciences of Ribeirão Preto, University of São Paulo, Ribeirão Preto, Brazil, ${ }^{2}$ Laboratory of Industrial Enzymology, Department of Pharmaceutical Sciences, School of Pharmaceutical Sciences of Ribeirão Preto, University of São Paulo, Ribeirão Preto, Brazil

Antimicrobial peptides (AMPs) are ubiquitous and multipotent components of the innate immune defense arsenal used by both prokaryotic and eukaryotic organisms. The search for new AMPs has increased in recent years, due to the growing development of microbial resistance to therapeutical drugs. In this work, we evaluate the effects of Tityus serrulatus venom (Tsv), its fractions and its major toxin Ts1, a beta-neurotoxin, on fungi growth. The fractions were obtained by ion-exchange chromatography of Tsv. The growth inhibition of 11 pathogenic and non-pathogenic filamentous fungi (Aspergillus fumigatus, A. nidulans, A. niger, A. terreus, Neurospora crassa, Penicillium corylophilum, P. ochrochloron, P. verrucosum, P. viridicatum, P. waksmanii, and Talaromyces flavus) was evaluated by quantitative microplate reader assay. Tsv (100 and $500 \mu \mathrm{g} / \mathrm{well}$, which correspond to 1 and $5 \mathrm{mg} / \mathrm{mL}$, respectively, of total soluble protein) was active in inhibiting growth of $A$. nidulans, $A$. terreus, $P$. corylophilum, and $P$. verrucosum, especially in the higher concentration used and at the first $30 \mathrm{~h}$. After this period, fungi might have used Tsv components as alternative sources of nutrients, and therefore, increased their growth tax. Only fractions IX, X, XI, XIIA, XIIB (3 and $7.5 \mu \mathrm{g} /$ well, which correspond to 30 and $75 \mu \mathrm{g} / \mathrm{mL}$, respectively, of total soluble protein) and Ts1 (1.5, 3, and $6 \mu \mathrm{g} /$ well, which correspond to $2.18,4.36$, and $8.72 \mu \mathrm{M}$, respectively) showed antifungal activity. Ts1 showed to be a non-morphogenic toxin with dose-dependent activity against $A$. nidulans, inhibiting $100 \%$ of fungal growth from $3 \mu \mathrm{g} /$ well $(4.36 \mu \mathrm{M})$. The inhibitory effect of Ts1 against $A$. nidulans growth was accompanied by fungistatic effects and was not amended by $1 \mathrm{mM} \mathrm{CaCl}_{2}$ or tetrodotoxin (46.98 and $\left.93.96 \mu \mathrm{M}\right)$. The structural differences between Ts1 and drosomycin, a potent cysteine-rich antifungal peptide, are discussed here. Our results highlight the antifungal potential of the first cysteine-containing scorpion toxin. Since Ts1 is a multifunctional toxin, we suggest that it could be used as a template in the design of engineered scorpion AMPs and in the search for new mechanisms of action of antifungal drugs.

Keywords: Tityus serrulatus, defensins, fungi, antifungal drugs, cysteine-rich antifungal proteins, antimicrobial peptides, antimycotic, drosomycin 


\section{INTRODUCTION}

Scorpion venoms are a rich source of peptide toxins, insoluble mucus, bioactive amines, hypotensins, proteinases, hyaluronidase, bradykinin-potentiating peptide, kallikrein inhibitor, allergenic proteins, and other peptides whose biological functions are still not clarified (Bordon et al., 2015). Their best studied toxins interact specifically with voltage-gated $\mathrm{Na}^{+}$and $\mathrm{K}^{+}$channels and are toxic both to vertebrates and invertebrates. $\mathrm{Na}^{+}$channel toxins have 61-76 amino acid residues, stabilized by four disulfide bonds, whereas the $\mathrm{K}^{+}$channel toxins present 22-47 amino acid residues, stabilized by three disulfide bonds (Becerril et al., 1997; Tytgat et al., 1999; Lewis and Garcia, 2003; Rodríguez de la Vega and Possani, 2004, 2005).

In the course of the evolution process, some arthropods such as scorpions have evolved, despite the others components, AMPs in their venom (Kuhn-Nentwig et al., 2004). The presence of AMPs in scorpion venom might be related to the protection of the venom gland against infection and also to facilitate the action of neurotoxins (Harrison et al., 2014). AMPs are pervasive and evolutionarily ancient tools of host innate defense against pathogens. They are widespread in nature and are found in bacteria, protozoa, plants, insects, fungi and mammals (Hegedus and Marx, 2013). Some of them are known as small cationic antimicrobial peptides (SCAMPs) or defensins (Zhu and Tytgat, 2004). Those peptides generally adopt an amphipathic structure with cationic and hydrophobic properties which may have a role in the interaction with the cell membranes of microorganism. Amphipathic $\alpha$-helical AMPs isolated from scorpion venoms function as part of the innate defense mechanism against different kinds of pathogens (Zasloff, 2002). Of the impressive number of antimicrobial structures reported, at least 50\% were identified in invertebrates (Bulet et al., 1999).

There is a great variation in function, structure, sensible organisms, expression pattern and origin of AMPs, what make their classification difficult and somewhat arbitrary so far (Hegedus and Marx, 2013). In spite of great differences in size and amino acid composition, most of the AMPs can be classified into 3 groups according to its structural characteristics: (1) lacking cysteine alpha-helical linear peptides, also known as non-disulfide-bridged peptides (NDBPs), (2) cysteine-containing peptides with disulfide bonds and (3) peptides with an overrepresentation of proline, histidine, tryptophan, or glycine residues (Bulet et al., 2004; Zhu and Tytgat, 2004; Harrison et al., 2014). To this date, over 40 scorpion AMPs have been characterized and classified among the first and second AMP classes, without any representatives on the third one (Harrison et al., 2016) (for review, see Harrison et al., 2014).

In regards to the second group, the first scorpion cysteinecontaining AMP was isolated from the Pandinus imperator venom and it was named scorpine (Conde et al., 2000). Scorpine was assayed against gram positive (Bacillus subtilis) and gram negative (Klebsiella pneumonia) bacteria and was active against

Abbreviations: A., Aspergillus; AMPs, antimicrobial peptides; N., Neurospora; NDBPs, non-disulfide-bridged peptides; P., Penicillium; PDA, potato dextrose agar; T., Talaromyces; Tsv, Tityus serrulatus venom; TTX, tetrodotoxin. both (minimal inhibitory concentration - MIC - 1-10 $\mu \mathrm{M}$ ). This toxin has a unique structure with a molecular mass of $8.3 \mathrm{kDa}$ stabilized by three disulfide bonds. Its $N$-terminal presents similarities with cecropins, while the $C$-terminal shows similarities with scorpions' defensins (Conde et al., 2000). On the following years, others scorpine-like toxins were isolated from the scorpions Opistophtalmus carinatus (opiscorpine 1-4), Heterometrus laoticus (heteroscorpine-1), Hadrurus gertschi (Hge-scorpine), Opisthacanthus cayaporum (Ocy39.87), and Urodacus yaschenkoi (UySCl 1-2) (Zhu and Tytgat, 2004; Uawonggul et al., 2007; Diego-Garcia et al., 2008; Schwartz et al., 2008; Luna-Ramirez et al., 2013) and expressed from the venom cDNA library of scorpion Euscorpiops validus (scorpine-like peptide Ev37) (Feng et al., 2013).

Remarkably, six AMPs from $T$. discrepans venom were described and named bactridines (Bacts 1-6). Those molecules are hydrophilic, non-amphipathic and positively charged polypeptides with four disulfide bonds stabilizing a chain of more than 60 amino acids (Diaz et al., 2009). Those peptides, especially Bact 2, have aroused the attention of scientific community but not due to their antimicrobial activity, which is not potent when compared to others AMPs. The spotlights put on Bact 2 rise on its activity as a $\beta$-modulator of $\mathrm{Na}^{+}$channel. Bactridines were the first group of scorpion toxins to combine those two functions (Peigneur et al., 2012; Harrison et al., 2014).

Despite the in depth studies concerning the antibacterial activity of AMPs from group 2, studies regarding the antifungal activity of those toxins remain limited. Drosomycin was the first antifungal peptide isolated from insects and is comprised of 44 amino acid residues linked by four disulfide bonds (Michaut et al., 1996). Recently, a cysteine-containing AMP from the Avicularia juruensis spider venom, designated as juruin, showed antifungal activity against Candida strains and Aspergillus niger (Ayroza et al., 2012). Antifungal activity was also described for pandinin2 from $P$. imperator venom (Corzo et al., 2001) and for seven synthetic peptides which had their primary sequence obtained through transcriptome analysis of T. obscurus, $H$. gertschi, and O. cayaporum venom glands (Guilhelmelli et al., 2016); however, all of them are NDBPs.

The fact that fungi are eukaryotes makes difficult the development of drugs that inhibit fungal growth, without a consequent toxicity to the host (Stephenson, 1997). Fungi are capable of causing superficial or severe, often lethal, invasive infections in humans, mainly in immunocompromised patients (transplant recipients under immunosuppressive therapy, cancer patients treated with cytotoxic drugs, and AIDS patients) who are highly susceptible to fungal infections (Ortiz et al., 2015). Aspergillosis is the most frequent fungal infection in severally ill patients and its prevalence has increased in the latest years (Vincent et al., 2009; Tortorano et al., 2012; Cabezas-Quintario et al., 2016). Moreover, increasing antifungal resistance has been reported for the existing antifungal agents. Some fungi are inherently resistant and the biofilm mode of fungal growth is highly resistant to the available drugs (Seneviratne and Rosa, 2016). Thereby, the search for new antifungal agents is urgently required. 
Based on that, this study shows the first antifungal screening of T. serrulatus venom (Tsv), Tsv fractions and Ts1, the major component of this venom, against 11 different pathogenic and non-pathogenic filamentous fungi: A. fumigatus, A. nidulans, A. niger, A. terreus, Neurospora crassa, Penicillium corylophilum, $P$. ochrochloron, $P$. verrucosum, $P$. viridicatum, $P$. waksmanii, and Talaromyces flavus. A. fumigatus is the main cause of opportunistic fungal infections in humans (Brakhage, 2005), while $A$. terreus causes superficial and invasive mycosis (Kniemeyer, 2011). The other evaluated fungal species of the genus Aspergillus play significant roles as model organisms in basic research and for manufacturing of a wide range of commercial enzymes (Pontecorvo et al., 1953; Baddley et al., 2003). T. flavus (formerly known as $P$. vermiculatum) and the genus Penicillium have been reported to be producers of secondary metabolites with antimicrobial, antiprotozoal, antitumoral, or insecticidal activities (Freitas et al., 2002; Elias et al., 2006). N. crassa is able to degrade phenolic pollutants (Luke and Burton, 2001), and P. corylophilum is a plant pathogen and a parasite of fish (Gozlan et al., 2014).

\section{MATERIALS AND METHODS}

\section{Soluble Venom}

Tityus serrulatus venom was obtained by electrical stimulation (Lowe and Farrell, 2011) of scorpions maintained at the vivarium "Biotério Central" (School of Medicine of Ribeirão Preto, University of São Paulo, Brazil), in accordance with the guidelines of the Brazilian College for Animal Experimentation (COBEA) and Ibama, Brazilian Institute of Environment. Desiccated Tsv was suspended in $0.9 \%(\mathrm{~m} / \mathrm{V}) \mathrm{NaCl}$ and centrifuged at $11,270 \times \mathrm{g}$, $25^{\circ} \mathrm{C}$, for $5 \mathrm{~min}$. The protein concentration of the soluble Tsv and Ts1 was estimated at $280 \mathrm{~nm}$ by a spectrophotometer (U2001, Hitachi Instrument Inc., Tokyo, Japan) using the extinction coefficient $\left(\varepsilon_{280 \mathrm{~nm}}^{1 \mathrm{mg}}\right)$ of 1.65 for the soluble Tsv (Pucca et al., 2014) and 3.548 for the pure Ts $1^{1}$. The protein concentration of the soluble Tsv fractions was estimated by $280 / 205 \mathrm{~nm}$ absorption method (Scopes, 1974).

\section{Purification Procedure}

Desiccated Tsv was fractionated on a CM-cellulose-52 column, resulting in the fractions designated as I to XIII. The eluted fraction XIII was rechromatographed on a $\mathrm{C} 18$ reversedphase (C18-RP) column (Shim Pack CLC-ODS $5 \mu \mathrm{m}$, $0.46 \mathrm{~cm} \times 25.0 \mathrm{~cm}$, Shimadzu Instruments Corp., Tokyo, Japan) using a fast protein liquid chromatography (FPLC) system and pure Ts1 was obtained, as previously described (Vasconcelos et al., 2005). The homogeneity of the samples was analyzed by Polyacrylamide Gel Electrophoresis (PAGE, 10\%) carried out according to Reisfeld et al. (1962) with modifications described by Arantes et al. (1989). The fractions I to XII-B eluted from the cationic chromatography and pure Ts1 (C18-RP-FPLC) were used in the subsequent assays.

\footnotetext{
${ }^{1}$ http://web.expasy.org/cgi-bin/protparam/protparam
}

\section{Fungi}

Aspergillus nidulans strain FGSC-A26 (biA1, veA1) and $N$. crassa (74 OR 8-1a, ATCC) were acquired from the Fungal Genetics Stock Center and American Type Culture Collection, respectively. The other fungi were isolated from Brazilian soil samples by Dr. Said S., identified and deposited in the collection of "Fundação André Tosello de Pesquisa e Tecnologia"2 (cct@fat.org.br) and cataloged as follows: A. fumigatus (CCT 7168), A. niger (CCT 7653), A. terreus (CCT 7640), P. corylophilum (CCT 7679), P. ochrochloron (CCT 7672), P. verrucosum (CCT 7680), P. viridicatum (CCT 7681), P. waksmanii (CCT 7684), and T. flavus (CCT 7682). Fungi cultures were maintained on PDA slants and preserved at $4^{\circ} \mathrm{C}$ with sub-culturing in regular intervals. Seven-days-old cultures (derived from the original stock cultures) grown on PDA tubes at $30^{\circ} \mathrm{C}$ were used as inoculum.

\section{Antifungal Activity Assay}

The microplate reader assay for fungal growth inhibition was done as previously described by Broekaert et al. (1990) with some modifications. For the preparation of fungi culture, inoculums were transferred to tubes containing PDA and allowed to grow at $30^{\circ} \mathrm{C}$ in the dark for 7 days. The harvest of spores was carried out flooding spores with sterile water and rubbing with a sterile spatula. The suspensions were then filtered through three layers of muslin. Spores were quantified in a Neubauer chamber for appropriate dilutions. The suspensions were diluted until reach the density of $2 \times 10^{4}$ spores $/ \mathrm{mL}$.

All experiments were carried out in sterile 96-well flat bottom microplates. Each sample dilution was tested in quadruplicate and the assays were performed at least twice on different days. Each well (final volume of $100 \mu \mathrm{L}$ ) contained $80 \mu \mathrm{L}$ of halfstrength potato dextrose broth $(12 \mathrm{mg} / \mathrm{mL}), 10 \mu \mathrm{L}$ of the spore suspension diluted in sterile distilled water containing approximately 200 spores, and $10 \mu \mathrm{L}$ of sterile saline in the absence (positive control) or presence of Tsv (100 and $500 \mu \mathrm{g}$, which correspond to 1 and $5 \mathrm{mg} / \mathrm{mL}$, respectively, of total soluble protein) or one of its fractions I-XIIB ( 3 and $7.5 \mu \mathrm{g}$, which correspond to 30 and $75 \mu \mathrm{g} / \mathrm{mL}$, respectively, of total soluble protein) or Ts1 $(1.5,3$, and $6 \mu \mathrm{g}$, which correspond to 2.18, 4.36 , and $8.72 \mu \mathrm{M}$, respectively, since its molecular mass is $6,873 \mathrm{Da}$ ). The negative control consisted of the reaction mixture in the absence of toxin and spores. After the inoculation, the microplates were homogenized for a few seconds on a microplate shaker and incubated at room temperature for $30 \mathrm{~min}$ prior to the first reading. The toxins (Tsv, its fractions and Ts1) were added to the medium at time zero. For the assay against $A$. nidulans, Ts 1 was added to the medium at time zero and after $6 \mathrm{~h}$ of growth. The absorbance of each well was measured at $600 \mathrm{~nm}$ by a 96 -well microplate reader (Sunrise, Tecan Inc., Mannedorf, Switzerland) during $48 \mathrm{~h}$, at different intervals of time (shown in the Figures 1-5). The data are expressed as mean \pm standard deviation (SD) and were analyzed using one-way ANOVA. Values of $p<0.05$ were considered statistically significant.

\footnotetext{
${ }^{2}$ http://fat.org.br/
} 

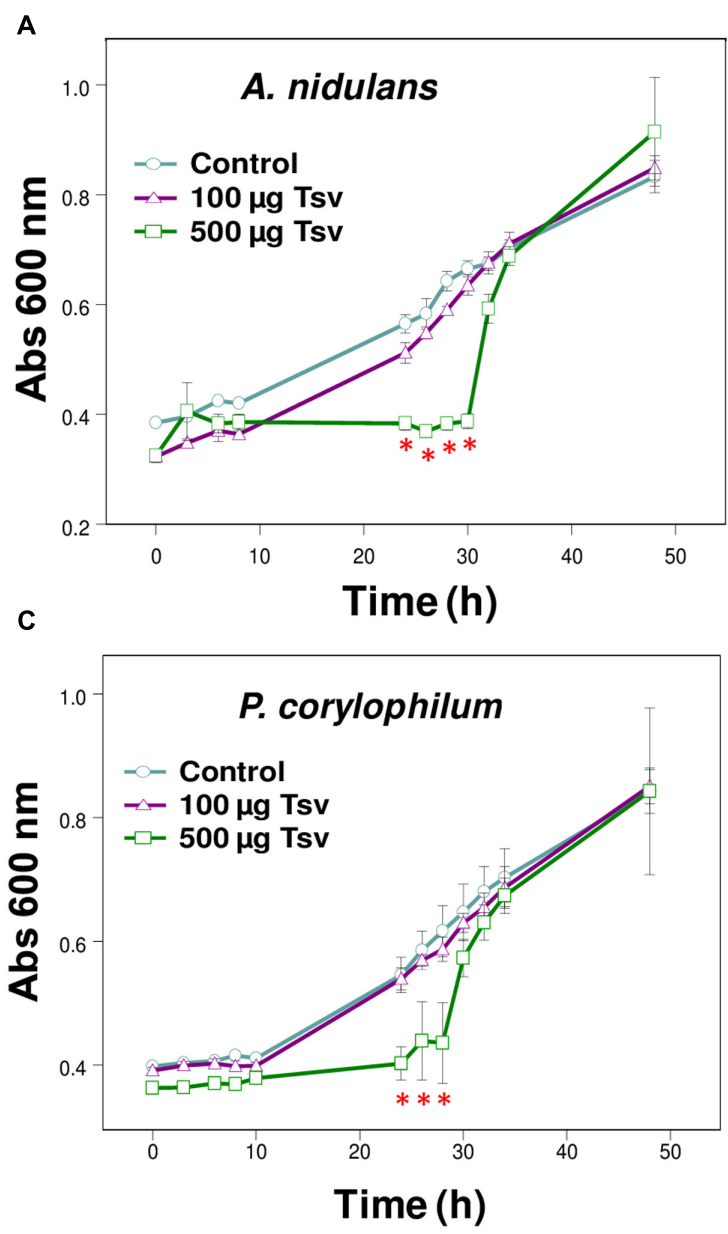

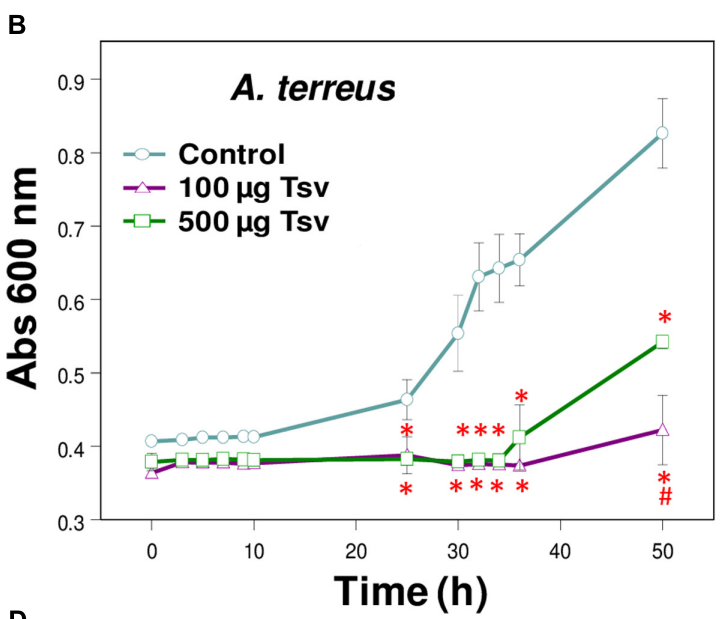

D

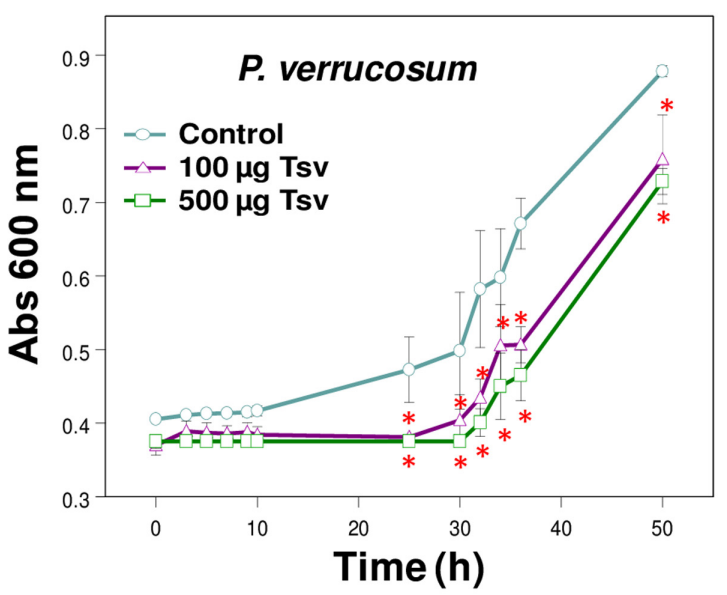

FIGURE 1 | Effect of Tsv on fungal growth. Fungal growth was monitored by measuring the absorbance of fungal culture at $600 \mathrm{~nm}$ during $48 \mathrm{~h}$, at different intervals of time. Control (open circle, no venom), Tsv $100 \mu \mathrm{g} /$ well (open triangle) and $500 \mu \mathrm{g} /$ well (open square). (A) A. nidulans; (B) A. terreus; (C) P. corylophilum; (D) P. verrucosum. Each point represents the mean \pm SD $(n=4)$ of the absorbance of fungal culture at each time. ${ }^{*} p<0.05$ compared to the control, ${ }^{*} p<0.01$ compared to the other experimental group (one-way ANOVA).

To evaluate the effect of $\mathrm{Ca}^{2+}$ treatment on the growth of the fungi $A$. terreus, $P$. corylophilum and $P$. verrucosum, the assay was carried out with the toxin Ts1 ( 3 and $6 \mu \mathrm{g} /$ well, which correspond to 4.36 and $8.72 \mu \mathrm{M}$, respectively) in the absence or presence of $1 \mathrm{mM} \mathrm{CaCl}_{2}$. The effect of Ts1 (1.5 and $3 \mu \mathrm{g} /$ well, which correspond to 2.18 and $4.36 \mu \mathrm{M}$, respectively) against $A$. nidulans was also carried out in the absence or presence of TTX (1.5 and $3 \mu \mathrm{g} /$ well, which correspond to 46.98 and $93.96 \mu \mathrm{M}$, respectively, since its molecular mass is $319.27 \mathrm{Da}$ ).

To evaluate if the toxin Ts1 is fungistatic or fungicide, all the content of the well after $48 \mathrm{~h}$ of incubation of Ts 1 (6 $\mu \mathrm{g} /$ well, which correspond to $8.72 \mu \mathrm{M}$ ) with $A$. nidulans ( $\sim 200$ spores/well) was applied onto plates containing PDA solid medium and incubated at $30^{\circ} \mathrm{C}$ for $24 \mathrm{~h}$. Then it was observed if there was growth of the fungus.

\section{Analysis of Fungus Morphology}

Saline solution of Ts 1 was previously filtered on a $0.22 \mu \mathrm{m}$ sterile membrane and aliquots $(25$ and $50 \mu \mathrm{L})$ at $0.6 \mathrm{mg} / \mathrm{mL}$ of total soluble protein were added to $3.2 \mathrm{~cm}$-internal diameter sterile Petri plates. The PDA medium $(1 \mathrm{~mL})$ at $45^{\circ} \mathrm{C}$ was added over the toxin solution, homogenized with a sterile $1 \mathrm{~mL}$-tip and allowed to solidify for about $30 \mathrm{~min}$, resulting at approximately 15 and $30 \mu \mathrm{g} / \mathrm{mL}(2.18$ and $4.36 \mu \mathrm{M})$ of Ts1 per plate. The fungus which was more significantly inhibited by Ts1 had approximately 200 spores $(10 \mu \mathrm{L})$ inoculated on a fragment of sterile dialysis membrane $(1.5 \mathrm{~cm} \times 1.5 \mathrm{~cm})$, overlaying PDA medium with toxin. Control group had no toxin. The plates were incubated at $30^{\circ} \mathrm{C}$ for $12 \mathrm{~h}$. After this period, the dialysis membranes were carefully removed and the hyphae morphology and spores germination were evaluated under a stereo microscope (Leica Microsystems, Wetzlar, Germany). The experiment was done in duplicate and the images were photographed.

\section{Hemolytic Assay}

Adult healthy male sheep were bled by jugular vein puncture and blood was collected in two volumes of Alsever's modified solution (Hoffmann and Mayer, 1977), which was used as 
A

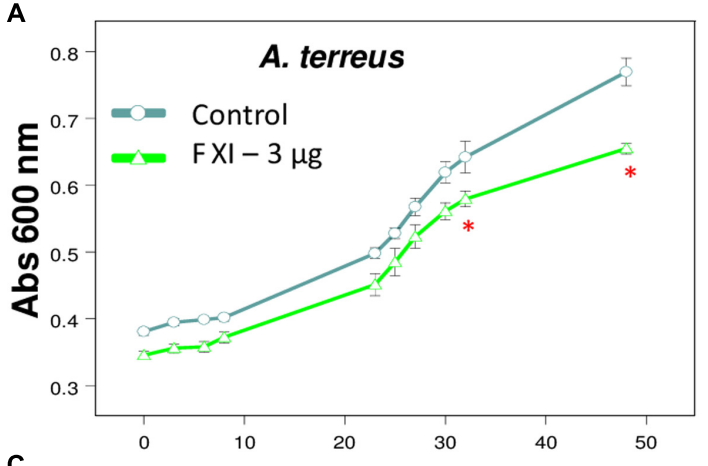

Time (h)

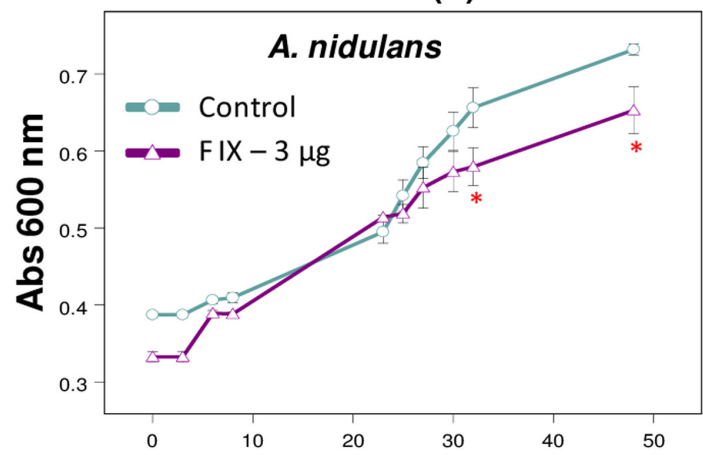

E

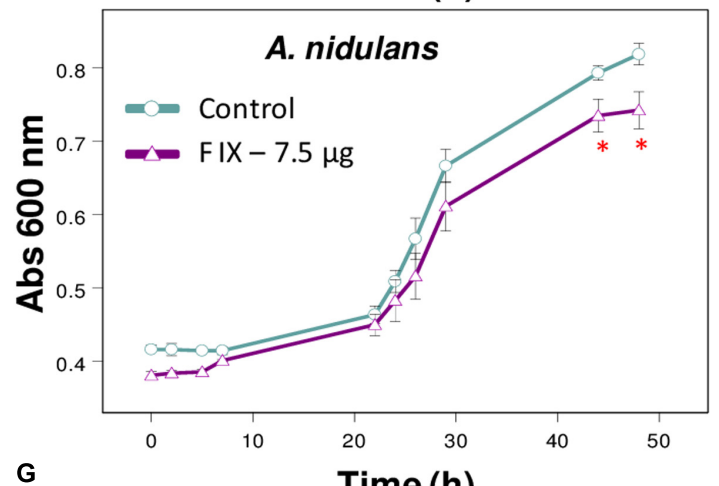

G

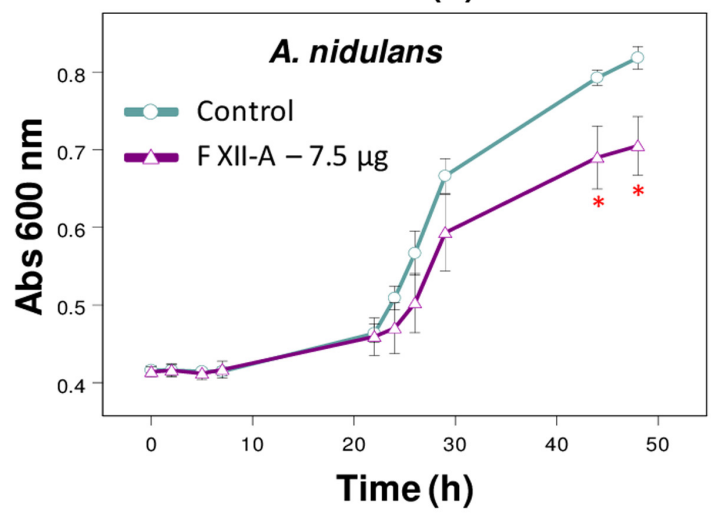

B

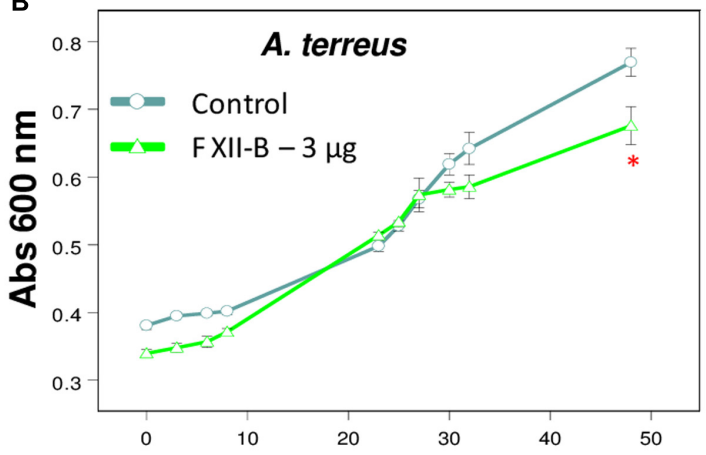

D

Time (h)

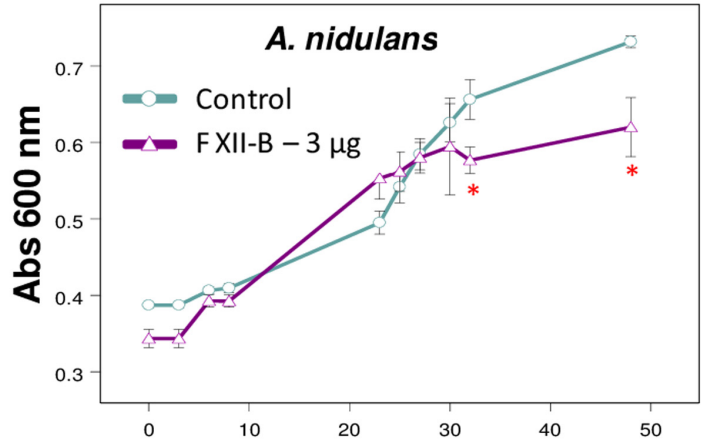

Time (h)

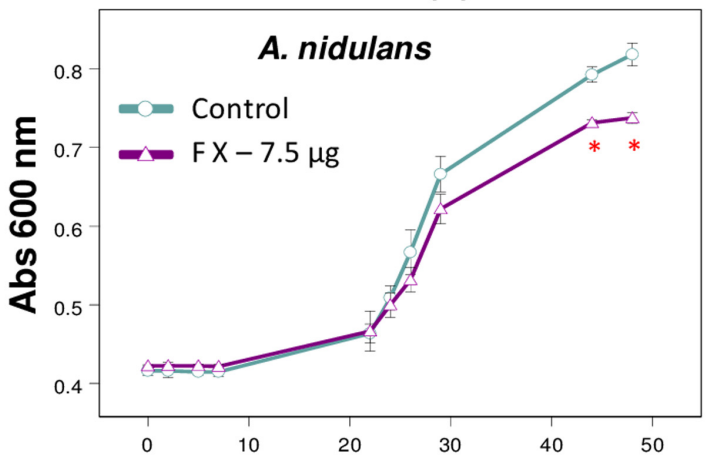

H

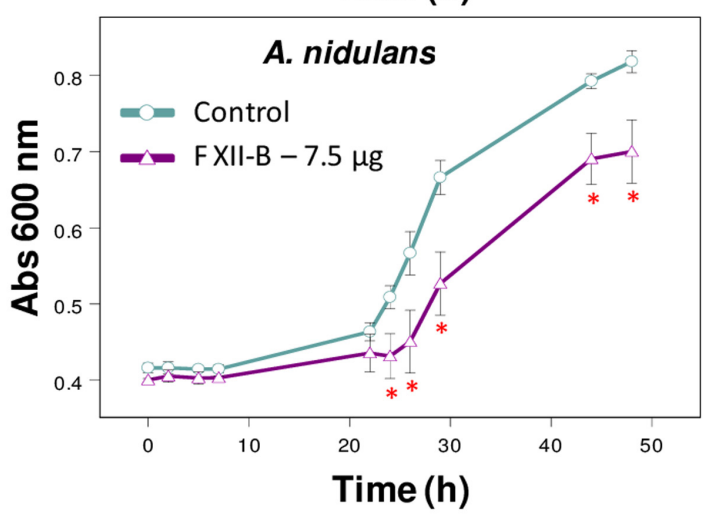

FIGURE 2 | Effect of Tsv fractions on fungal growth. (A,B) A. terreus using $3 \mu \mathrm{g} /$ well of fractions (A) XI and (B) XII-B. (C,D) A. nidulans using $3 \mu \mathrm{g} /$ well or (E-H) $7.5 \mu \mathrm{g} /$ well of fractions. (C,E) IX, (D,H) XII-B, (F) X, and (G) XII-A. Fungal growth was monitored by measuring the absorbance of fungal culture at $600 \mathrm{~nm}$ during $48 \mathrm{~h}$, at different intervals of time. Control (open circle, no venom), fractions (open triangle). Each point represents the mean \pm SD $(n=4)$ of the absorbance of fungal culture at each time. ${ }^{*} p<0.05$ compared to the control (one-way ANOVA). 
A

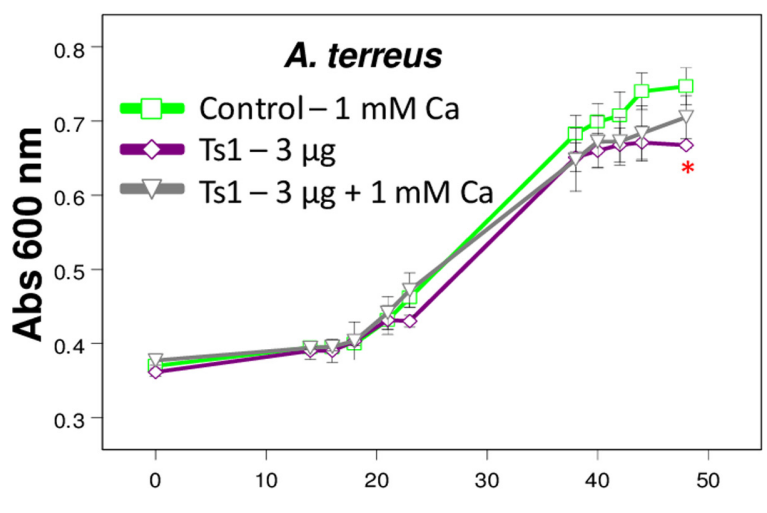

C
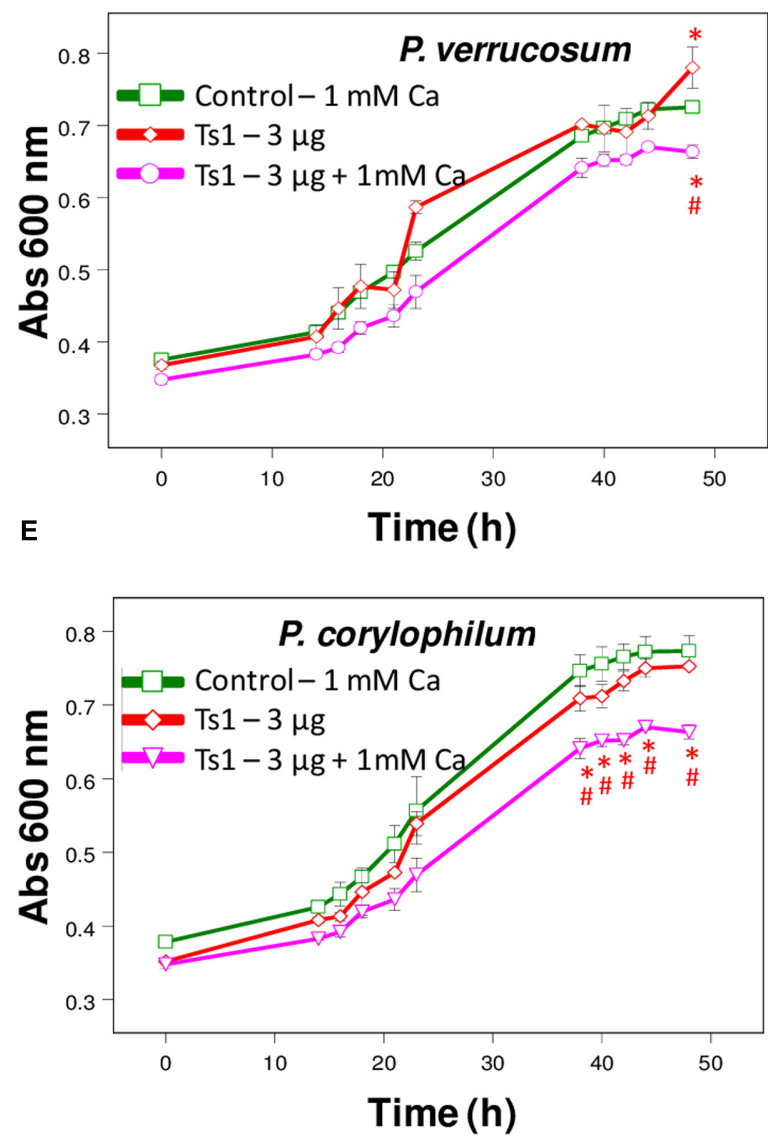

B
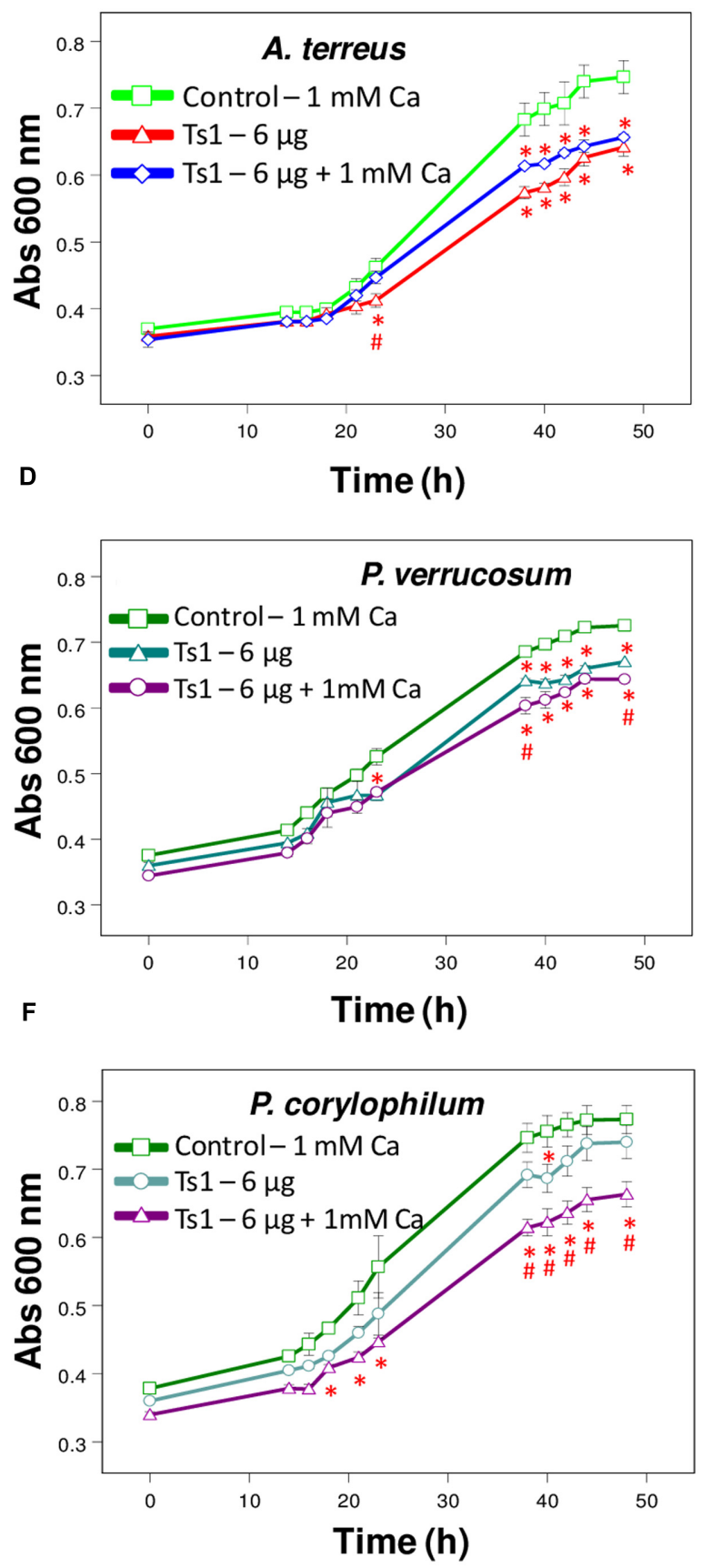

FIGURE 3 | Effect of Ts1 on fungal growth. Control (open circle, $1 \mathrm{mM} \mathrm{Ca}^{2+}$, no venom), (A,C,E) Ts1 (3 $\mu \mathrm{g} /$ well) or (B,D,F; $6 \mu \mathrm{g} /$ well), in the presence or absence of $1 \mathrm{mM} \mathrm{Ca}^{2+}$ were evaluated on $\mathbf{( A , B ) ~ A . ~ t e r r e u s ~ ( C , D ) , ~ P . ~ v e r r u c o s u m , ~ a n d ~ ( E , F ) ~ P . ~ c o r y l o p h i l u m ~ g r o w t h . ~ F u n g a l ~ g r o w t h ~ w a s ~ m o n i t o r e d ~ b y ~ m e a s u r i n g ~ t h e ~ a b s o r b a n c e ~}$ of fungal culture at $600 \mathrm{~nm}$ during $48 \mathrm{~h}$, at different intervals of time. Each point represents the mean $\pm \mathrm{SD}(n=4)$ of the absorbance of fungal culture at each time. ${ }^{*} p<0.05$ compared to the control, $\# p<0.01$ compared to the other experimental group (one-way ANOVA).

anticoagulant. All animal handling procedures and protocols were performed according to the National Counsel for animal experimentation recommendations (Conselho Nacional de Controle de Experimentação Animal - CONCEA). Animal use was approved by the Committee for Ethics in Animals
Utilization of University of São Paulo (n. 05.1.637.53.6). Sheep blood was centrifuged and the plasma and buffy coat were discarded. Red cells were washed three times in phosphate buffered saline (PBS). The red cells solution was standardized in a spectrophotometer (absorbance at $700 \mathrm{~nm}$ adjusted to 
A

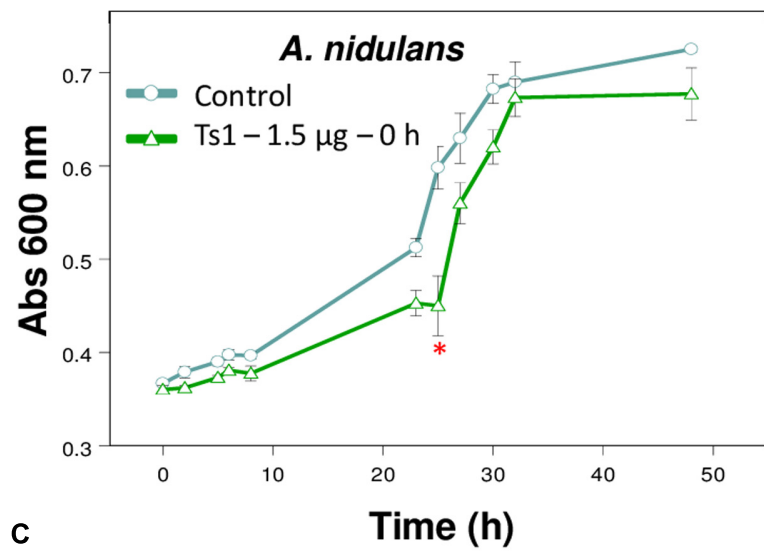

B

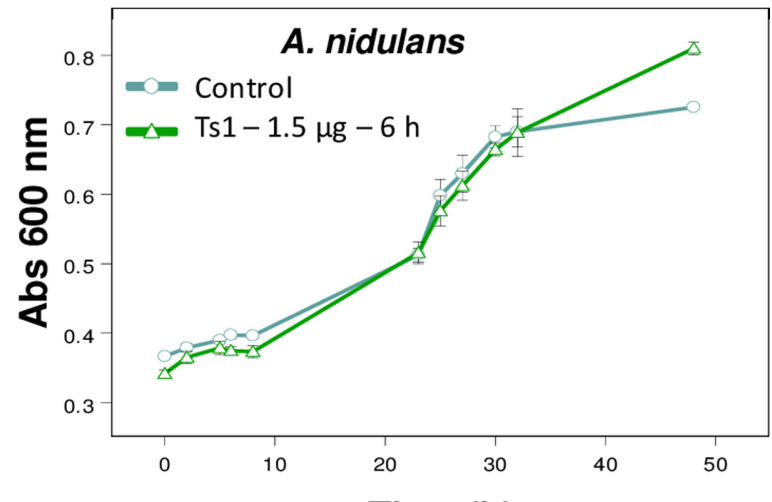

D
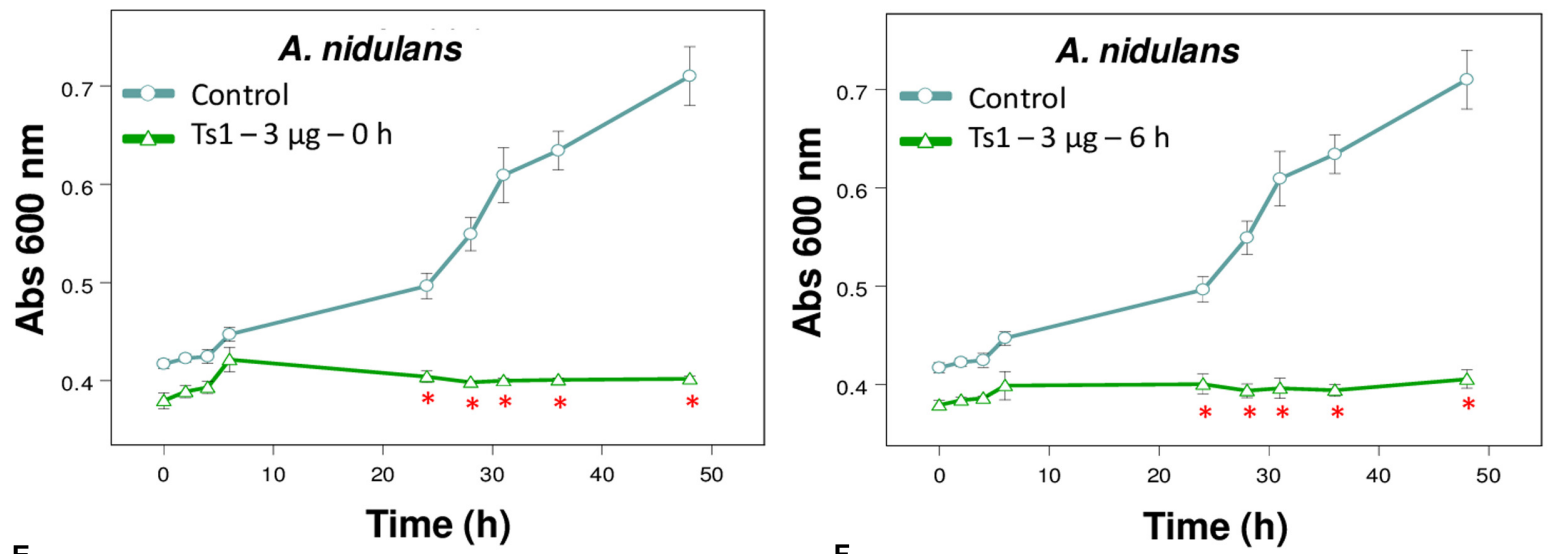

$\mathbf{E}$

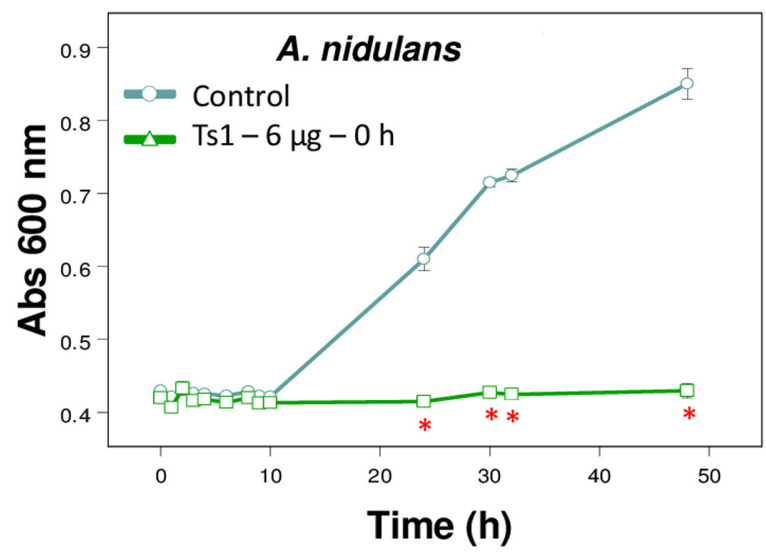

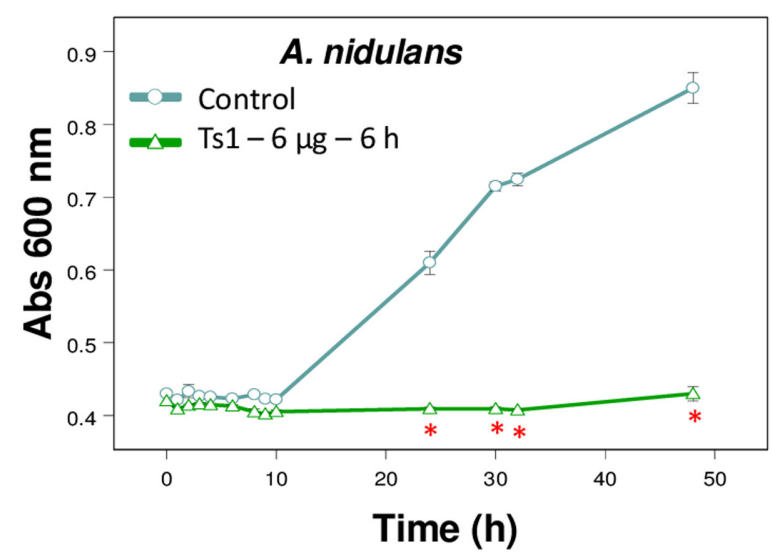

FIGURE 4 | Effect of different amounts of Ts1 on Aspergillus nidulans growth at different addition time. Ts1 (open triangle; A,B) $1.5 \mu \mathrm{g} / \mathrm{well}$, (C,D) $3 \mu \mathrm{g} / \mathrm{well}$ or (E,F) $6 \mu \mathrm{g} /$ well was added to culture medium (A,C,E) at zero time or (B,D,F) after $6 \mathrm{~h}$. Control (open circle, no toxin). Fungal growth was monitored by measuring the absorbance of fungal culture at $600 \mathrm{~nm}$ during $48 \mathrm{~h}$, at different intervals of time. Each point represents the mean $\pm \operatorname{SD}(n=4)$ of the absorbance of fungal culture at each time. ${ }^{*} p<0.05$ compared to the control (one-way ANOVA).

$0.70-0.75)$ to contain approximately $1.7 \times 10^{8}$ cells $/ \mathrm{mL}$ (counted in a Neubauer chamber).

To evaluate the lytic activity of Tsv and Ts1, $60 \mu \mathrm{L}$ of the standardized red cells solution was incubated with $60 \mu \mathrm{L}$ of PBS and $30 \mu \mathrm{L}$ of Tsv $(500 \mu \mathrm{g})$ or Ts1 $(6 \mu \mathrm{g})$ at $37^{\circ} \mathrm{C}$, for
$30 \mathrm{~min}$. Then the samples were cooled in an ice bath, mixed with cold PBS $(150 \mu \mathrm{L})$ and centrifuged at $480 \times g$ for $10 \mathrm{~min}$. The percentage of hemolysis was determined by measuring the absorbance of the supernatant at $412 \mathrm{~nm}$ (Little and Rumsby, 1980). 

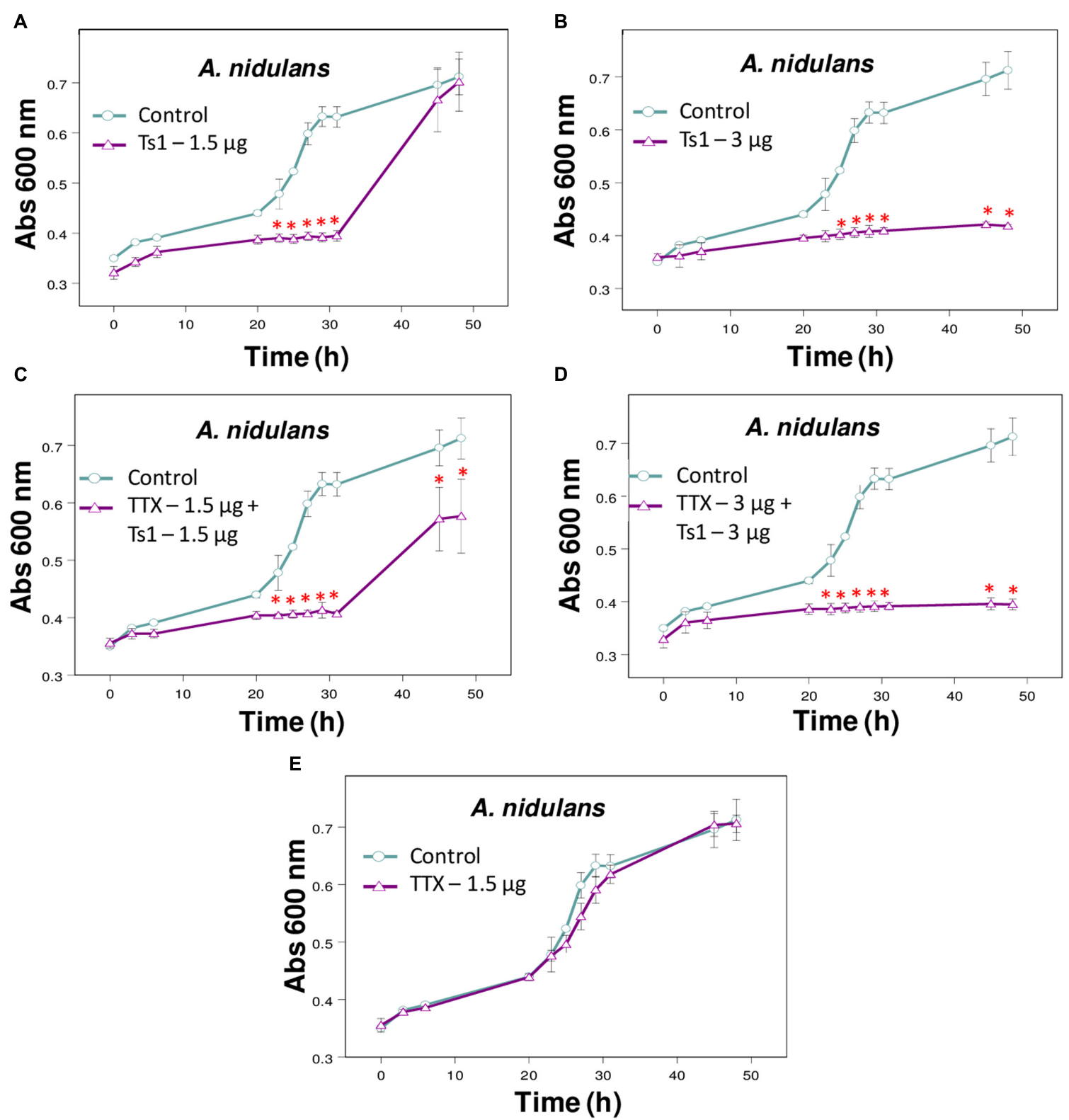

FIGURE 5 | Effect of Ts1 on A. nidulans growth in the presence of TTX. Fungal growth was monitored by measuring the absorbance of fungal culture at 600 nm during $48 \mathrm{~h}$, at different intervals of time. Control (open circle, no toxin), Toxins (open triangle). (A) Ts1, $1.5 \mu \mathrm{g} / \mathrm{well}$; (B) Ts1, $3 \mu \mathrm{g} / \mathrm{well}$; (C) TTX, 1.5 $\mu \mathrm{g} / \mathrm{well}+\mathrm{Ts} 1$, $1.5 \mu \mathrm{g} /$ well; (D) TTX, $3 \mu \mathrm{g} /$ well + Ts1, $3 \mu \mathrm{g} /$ well; (E) TTX, $1.5 \mu \mathrm{g} /$ well. Each point represents the mean \pm SD $(n=4)$ of the absorbance of fungal culture at each time. $* p<0.01$ compared to the control (one-way ANOVA). (C,D) TTX was added to the medium with fungus at zero time and incubated during 30 min. After that, Ts1 was added.

\section{Ts1 Alignment and Structure Comparison}

The primary structure of Ts1 was compared with other AMPs deposited in databanks. The amino acid sequences were retrieved from the Universal Protein Resource Knowledgebase ${ }^{3}$ or from the Protein Data Bank ${ }^{4}$. The amino acid sequences were as follows: Ts1 [PDB: 1NPI], drosomycin [PDB: 1MYN], bactridin1 [Swiss-Prot: P0CF39] and bactridin-2 [Swiss-Prot: P0CF37].

${ }^{3}$ www.uniprot.org

${ }^{4}$ http://www.rcsb.org/pdb/home/home.do
The alignment and the identity percentage were performed using Clustal Omega website, version 1.2.4 (Sievers et al., 2011).

For protein structure alignment and comparison, the algorithm TM-align (Zhang and Skolnick, 2005) was used. The superposed full-atom structure of the entire chains (without ligands and solvent) of Ts1 and drosomycin was performed 
by VMD (Visual Molecular Dynamics ${ }^{6}$ ) (Humphrey et al., 1996). The structures and sequences were compared using MultiSeq tool (Roberts et al., 2006) incorporated in VMD and the structure superposition was generated with the PyMOL Molecular Graphics System (DeLano, 2002).

\section{RESULTS}

\section{Purification of Ts1}

Ts1 was isolated as previously described (Vasconcelos et al., 2005) and represented around 16\% of Tsv (Supplementary Figures $\mathrm{S} 1 \mathrm{~A}, \mathrm{~B})$. The symmetry of the peak eluted from C18 reversedphase column (Supplementary Figure S1B) is an indicative of the homogeneity of the sample, which was later confirmed through PAGE, where Ts1 appeared as a single electrophoretic band (data not shown).

\section{Antifungal Activity Assay}

The present screening evaluated the growth patterns of A. fumigatus, A. nidulans, A. niger, A. terreus, N. crassa, P. corylophilum, P. ochrochloron, $P$. verrucosum, $P$. viridicatum, $P$. waksmanii and T. flavus in the presence of Tsv (100 and $500 \mu \mathrm{g} /$ well, which correspond to 1 and $5 \mathrm{mg} / \mathrm{mL}$, respectively, of total soluble protein) and in control condition. The results show a high inhibitory effect of Tsv on the growth of $A$. nidulans, A. terreus $P$. corylophilum, and $P$. verrucosum, especially in the higher concentration used and at the first $30 \mathrm{~h}$, showing a dosedependent antifungal activity (Figures 1A-D). On the other hand, Tsv increased the growth of N. crassa, and P. waksmanii, but had no effect on the other analyzed fungi (A. fumigatus, $P$. ochrochloron, $P$. viridicatum and $T$. flavus) at the tested doses (100 and $500 \mu \mathrm{g} /$ well, which correspond to 1 and $5 \mathrm{mg} / \mathrm{mL}$, respectively, of total soluble protein; data not shown).

The fractions isolated from Tsv (Supplementary Figure S1A) were tested against the same wide range of fungi species. Fractions XI and XIIB (3 $\mu$ g/well, which correspond to $30 \mu \mathrm{g} / \mathrm{mL}$ of total soluble protein) were active against $A$. terreus (Figures 2A,B). Fractions $\mathrm{X}$ and XIIA (7.5 $\mu \mathrm{g} /$ well, which correspond to $75 \mu \mathrm{g} / \mathrm{mL}$ of total soluble protein), IX and XIIB (3 and $7.5 \mu \mathrm{g} /$ well, which correspond to 30 and $75 \mu \mathrm{g} / \mathrm{mL}$, respectively, of total soluble protein) showed antifungal activity against $A$. nidulans (Figures $\mathbf{2} \mathbf{C}-\mathbf{H}$ ).

Ts1 shows a dose-dependent inhibition on the growth of A. terreus, $P$. corylophilum and $P$. verrucosum (Figures 3A-F). The addition of $1 \mathrm{mM} \mathrm{CaCl} 2$ did not alter the effect of Ts 1 on the growth of $A$. terreus (Figures $3 \mathbf{A}, \mathbf{B}$ ), but significantly potentiated the inhibition effect of Tslon the growth of $P$. verrucosum (Figures 3C,D) and of $P$. corylophilum (Figures 3E,F).

Figure 4 shows the effects of Ts 1 on the growth of $A$. nidulans on the different tested concentrations $(1.5,3$ and $6 \mu \mathrm{g} /$ well, which correspond to $2.18,4.36$, and $8.72 \mu \mathrm{M}$, respectively) and on the different times of spores' germination $(0$ and $6 \mathrm{~h})$. Ts 1 was able to inhibit the fungal growth in a dose-dependent manner (Figures 4A-F) into 96-well flat bottom microplates, showing

\footnotetext{
${ }^{6}$ http://www.ks.uiuc.edu/Research/vmd/
}

$100 \%$ inhibition from $3 \mu \mathrm{g} /$ well $(4.36 \mu \mathrm{M})$. The inhibitory effect of Ts1 $(1.5 \mu \mathrm{g} /$ well, which correspond to $2.18 \mu \mathrm{M})$ was statistically significant when the toxin was added to the medium with fungus spores at zero time and incubated during $24 \mathrm{~h}$ (Figure 4A). Ts1 (6 $\mu \mathrm{g} /$ well, which correspond to $8.72 \mu \mathrm{M}$ ) exhibits a fungistatic activity against $A$. nidulans, since we have observed viable spores on the content of the well after incubation with the toxin (data not shown).

The addition of TTX did not change significantly the inhibitory effect of Ts1 on the growth of $A$. nidulans (Figures 5A-E).

\section{Analysis of Fungus Morphology}

The toxin Ts1 was able to reduce the elongation of hyphae from $A$. nidulans in a dose-dependent manner, without causing morphological alterations (Supplementary Figure S2).

\section{Hemolytic Assay}

Tityus serrulatus venom and its major toxin Ts1 showed to be non-cytolytic on erythrocytes, even with the higher tested doses (500 and $6 \mu \mathrm{g}$, which correspond to $5 \mathrm{mg} / \mathrm{mL}$ and $8.72 \mu \mathrm{M}$, respectively; data not shown).

\section{Ts1 Alignment and Structure Comparison}

Ts1 shares the highest identity score (63.9\%) with bactridin2 (Figure 6). Although the percent identity with drosomycin is low $\left(27.9 \%\right.$, Figure 6), the $Q_{\mathrm{H}}$ value of the superposed Ts1 and drosomycin structures is above 0.5 (Figure 7A). The $\mathrm{Q}_{\mathrm{H}}$ measures structural conservation (Eastwood et al., 2001). When $\mathrm{Q}_{\mathrm{H}}$ has a low score $(0.1-0.3)$, structures are not aligned well. The TM-score $=0.50184$ (data not shown) was normalized by length of Ts1 chain using TM-align. TM-score below 0.3 shows random structural similarity (Zhang and Skolnick, 2005). The disulphide bonds are shown in the Ts1 (Figure 7B) and drosomycin (Figure 7C) structures.

\section{DISCUSSION}

Searches for new antibacterial and antifungal peptides have attracted the attention of many researches in recent years. This excitement is due to the rush in finding new therapeutic agents to deal with the emerging microbial resistance (Pimenta and De Lima, 2005). The spotlights have been pointed toward the AMPs and the use of those molecules as models of unique scaffolds for the development of new antibiotics drugs (Harrison et al., 2014). AMPs represent an ancient defense mechanism against invasive pathogens and are present in several groups of animals. These peptides have been reported as one of the many components present in the complex mixture of scorpion venoms (Harrison et al., 2014).

The antifungal screening performed in the present work showed the efficiency of Tsv in reducing the growth of $A$. nidulans, A. terreus, $P$. verrucosum and $P$. corylophilum at the first $30 \mathrm{~h}$ (Figures 1A-D). On the other hand, Tsv increased the growth of the fungi $N$. crassa and P. waksmanii (data not shown). Since scorpion venoms are composed by a complex 
1234567890123456789012345678901234567890123456789012345678901234

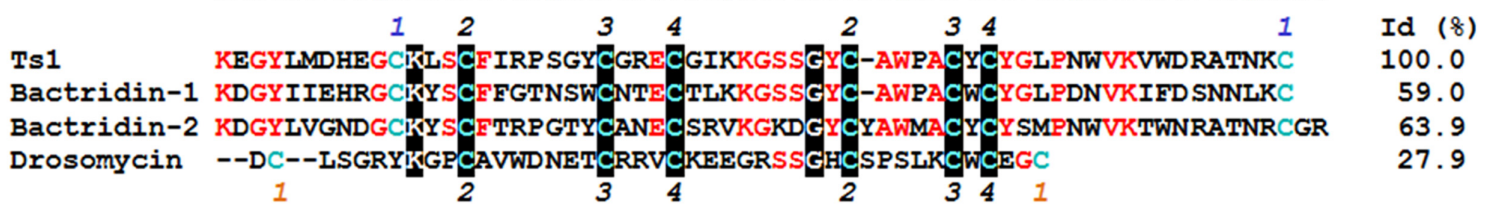

FIGURE 6 | Multiple sequence alignment of Ts1 and AMPs. The alignment and identity (\%) of Ts1 [PDB: 1NPI], drosomycin [PDB: 1MYN], bactridin-1 [Swiss-Prot: POCF39] and bactridin-2 [Swiss-Prot: POCF37] were performed using Clustal Omega version 1.2.4. The conserved amino acid residues are in red, and those highly conserved are highlighted in black. Cys residues are in blue. The numbers on the top and on the bottom refer to the disulfide bonds - the common bonds are in black; the orange and blue numbers represent the distinct bonds among drosomycin and the other toxins, respectively.

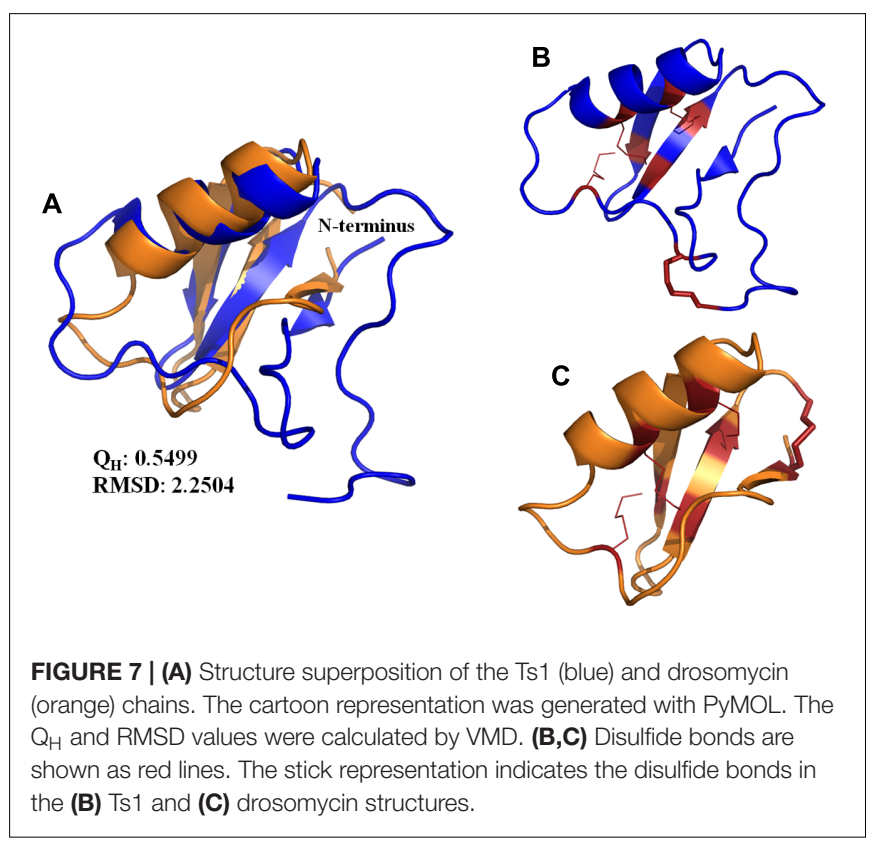

mixture of mucus, low molecular mass molecules and many other peptides and proteins, those species of fungi might have used these components as alternative sources of nutrients, and therefore, increased their growth tax.

The fractions I-XIIB isolated from Tsv were also tested against those 11 fungi species. Fractions XI and XIIB were effective against $A$. terreus only in the lowest tested dose after $48 \mathrm{~h}$ of incubation. At higher doses, some venom components may be exerting different and antagonistic effects which could be affecting the fractions' inhibitory activity. Fractions IX, X, XIIA and XIIB reduced the growth of $A$. nidulans. Ts fractions had no effect on the other fungi ( $P$. corylophilum and $P$. verrucosum) affected by the whole venom, maybe because they were tested at doses below the effective dose able to cause inhibition.

Tityus serrulatus venom fractionation procedure as described by Arantes et al. (1989) directly yields the toxin Ts1 in the fraction XIII, whose purity was confirmed by reversed-phase chromatography on a C18 column and PAGE. Ts1, also known as TsTX-I, toxin- $\gamma$, Toxin $\mathrm{T}_{2}$ IV, Toxin Ts7, Ts VII, Toxin VII, TsTXVII, Tityustoxin VII, Toxin III-10, Toxin II-11, or Toxin $\mathrm{T}_{1}$ VIII (Bordon et al., 2015), is the most abundant and potent toxin from the venom of the Brazilian yellow scorpion T. serrulatus and was the first biochemically characterized toxin of this arthropod (Possani et al., 1977; Arantes et al., 1989). Because of the relatively high amount of this toxin on Tsv, accounting for approximately $16 \%$ of the soluble venom and the high toxicity against both mammals and insects, many studies concerning Ts1 have been carried out over the years (Cologna et al., 2009; Bordon et al., 2015). Recently, a gamut of effects on $\mathrm{Na}^{+}$channels (Peigneur et al., 2015) and an important immunomodulatory activity on macrophages have been reported for Ts1 (Petricevich et al., 2007; Zoccal et al., 2011, 2014).

Despite the number of studies which investigated Ts1, the present work describes for the first time the antifungal screening using this well known toxin. On the past years, excepting the $\mathrm{K}^{+}$ channels blockers toxins which are related to defensins, most of the AMPs described from scorpion venoms were characterized as linear amphipathic peptides (Bulet et al., 2004). However, the identification of the Bactridines in 2009 (Diaz et al., 2009) has changed this concept.

In addition to the antimicrobial activity, bactridines, similarly to Ts1 with which share approximately $60 \%$ of sequence identity, showed effect on $\mathrm{Na}^{+}$channels and were classified as $\beta$-modulators of these channels. Bactridines were reported to change the bacterial membrane sodium permeability (Diaz et al., 2009). However, the electrophysiological studies revealed no effect of those toxins on the oocyte-expressed $\mathrm{NaChBac}$ channel, suggesting they may act on others isoforms of $\mathrm{Na}^{+}$channels, or even in other sodium translocation pathways different from ion channels (Diaz et al., 2009; Peigneur et al., 2012). Equivalently, Ts1 also did not present affinity for $\mathrm{NaChBac}$ channel (Peigneur et al., 2015). It is noteworthy that bactridines were the first scorpion toxins presenting antibacterial activity and action on $\mathrm{Na}^{+}$channels (Peigneur et al., 2012), while Ts1 is the first $\mathrm{Na}^{+}$ channel toxin with antifungal activity (this work).

Regarding the antifungal effect of Ts1 against $P$. corylophilum and $P$. verrucosum, the activity was strikingly potentiated by the addition of $1 \mathrm{mM} \mathrm{CaCl}$. Adversely, it was reported that the supplementation with cations on test medium does not increase, but does reduce the antifungal activity of defensins. Plant, insect and mammalian defensins had their antimicrobial activity reduced in the presence of divalent cations, especially $\mathrm{Ca}^{2+}$ (Lehrer et al., 1988; Cociancich et al., 1993; Osborn et al., 1995). Results previously reported indicate that a direct interaction occurs between the fungus and the cations, which protects 
the fungus against the inhibitory effect of the protein without conformational changes (Terras et al., 1992). Ionic strength antagonism is dependent on the fungus and the conformation of the putative target site (Terras et al., 1992; Osborn et al., 1995). For instance, the growth medium supplemented with $5 \mathrm{mM}$ $\mathrm{CaCl}_{2}$ caused a 1.7 -fold reduction of inhibitory activity of RsAFP2 (an antifungal protein from radish seeds) against Fusarium culmorum and more than 50-fold reduction against Trichoderma hamatum (Terras et al., 1992). The offbeat activity of Ts1 against those two fungi still need to be further explored.

Concerning the inhibitory effect of Ts1 against A. nidulans, this event was accompanied by fungistatic effects and was not disturbed significantly by the addition of TTX at all tested conditions. TTX is a potent $\mathrm{Na}^{+}$channel blocker (Narahashi et al., 1964), for which there is no known antidote (Bane et al., 2014). In this way, these results indicate that the antifungal activity of Ts1 is not related to its interaction with voltagegated $\mathrm{Na}^{+}$channels. Fungal genomes contain genes encoding $\mathrm{K}^{+}$, $\mathrm{Ca}^{2+}$ and transient receptor potential (Trp) channels, but not voltage-gated $\mathrm{Na}^{+}$channels or ligand-gated channels (Prole and Taylor, 2012). However, fungal calcium channels were reported to be closed related to sodium leak channels, non-selective (NALCN) (Liebeskind et al., 2012). Those newly described channels allow the passive flow of sodium (and other cations) across the cell membrane of neurons, modulating the neuronal resting potential (Ghezzi et al., 2014) and working as a sensor that indirectly affects membrane permeability (Senatore et al., 2013). The effects of Ts 1 on these channels were never described so far and therefore NALCN could represent a crosshair to elucidate the mechanism of action of this antifungal toxin. Thus, further studies to unveil this conundrum are still required. Nevertheless, based on our results, we can already stress that the described antifungal activity of Ts1 is not related to its action on voltage-gated $\mathrm{Na}^{+}$channels. In addition, our results suggest that some antifungal peptides, such as Ts1, may play their role by different modes-of-action, which might be related to uncharted receptors or other little-known channel types present on the fungus membrane. As a matter of fact, five toxins (F2 to F6) isolated from T. discrepans scorpion venom, with masses between 6,924.6 and 7328.8 Da, typical of scorpion toxins acting on sodium channels, showed antifungal effects against the phytopathogenic fungus Macrophomina phaseolina through three different ways: inhibiting fungus esterases and altering $\mathrm{Na}^{+}$membrane permeability and/or sterol biosynthesis (Joya et al., 2011). In this way, in-depth studies regarding Ts1 antifungal activity are necessary, in order to answer further questions, like its mechanism of action and its respective MIC or minimum effective concentration (MEC) quality control (QC) limits.

Another issue to be considered is that Ts1 is a cationic peptide [pI $\sim 8.67$ (Cologna et al., 2009)]. Cationic peptides may destabilize membranes at a given concentration (Remijsen et al., 2010), but the mechanism of action of some of them is still unclear (Jenssen et al., 2006; Mookherjee and Hancock, 2007). Parabutoporin is an example of scorpion cationic amphipathic lysine-rich and cysteine-free peptide with antimicrobial, antifungal and immunoregulatory activities
(Remijsen et al., 2010). In silico and circular dichroism analyses of seven antifungal NDBPs highlighted the relevance of cationicity and amphipathicity for their antimicrobial activity (Guilhelmelli et al., 2016). AamAP1-Lysine, a synthetic peptide analog of a scorpion AMP, was modified to increase the positive charge from the native peptide, resulting in bactericidal activity through membrane damage and permeabilization caused by $\beta$-galactosidase releasing from bacterial cells (Almaaytah et al., 2014). Designed cationicity-enhanced analogs of natural AMPs from Androctonus crassicauda, A. aeneas, Vaejovis mexicanus smithi, U. yaschenkoi and U. manicatus scorpion venoms exhibited higher potency and spectra of antimicrobial activity (Du et al., 2014, 2015; Luna-Ramirez et al., 2017; Pedron et al., 2017).

Regarding the structural features of Ts1, its primary structure is composed of 61 amino acid residues with a molecular mass of 6,873 Da (Pinheiro et al., 2003). The tertiary structure of this toxin has been determined by X-Ray crystallography and shows a conserved core formed by three antiparallel $\beta$-strands and an $\alpha$-helix stabilized by four disulfide bonds (Polikarpov et al., 1999). This conserved motif is known as Cysteine Stabilized $\alpha \beta(\operatorname{CS} \alpha \beta)$ motif and is also found in defense peptides exhibiting antibacterial and antifungal activities, such as insect defensin A, plant thionins and plant defensins (Landon et al., 1997). The deletion of a small loop of the defensin structure resulted in a $\mathrm{K}^{+}$channel blocking neurotoxin, providing evidences that $\mathrm{K}^{+}$ channel toxins and defensins are evolutionarily related (Zhu et al., 2014).

In an attempt to establish a structure-activity relationship for the antifungal effect of Ts1, we performed the structure alignment of Ts1 and drosomycin, a potent cysteine-rich antifungal peptide. Multiple sequence structure alignment reveals much important information, e.g., proteins with similar functions tend to be found with similar structural features. Ts1 and drosomycin structures displayed good alignment, as shown by the $\mathrm{Q}_{\mathrm{H}}$ and RMSD (root-mean-square distance) values. Additionally, the TM-score above 0.5 indicates that Ts 1 and drosomycin have the same fold. Although few amino acid residues are conserved between Ts1 and drosomycin (27.9\% of sequence identity), both of them share the same structural CS $\alpha \beta$ scaffold. Ts1 structure shows a longer $C$-terminal loop than drosomycin and a disulfide bond with distinct position linking the $C$ - and $N$-domains.

Drosomycin has a potent antifungal activity while it is ineffective against yeasts and bacteria and has no hemolytic effect on bovine erythrocytes (Bulet et al., 1999). Concerning the modeof-action, the distinctive activity of drosomycin on $N$. crassa and its mutant indicated a possible interaction of the peptide with fungal sphingolipid receptors, resulting in fungal cell death due to membrane permeabilization (Gao and Zhu, 2008; Wilmes et al., 2011).

The fungicidal activity of drosomycin against $N$. crassa has been reported and has shown that this compound is a morphogenic peptide (Fehlbaum et al., 1994). Morphogenic defensins slow down hyphal elongation associated to an increase in hyphal branching, whereas non-morphogenic defensins reduce hyphal extension with no pronounced morphological distortions (Osborn et al., 1995; Aerts et al., 2008). 
Based on mutation or deletion assays, it has been proposed that the effects observed on hyphae morphology may be explained by the presence or absence of hydrophobic residues in the turn connecting strands II and III of CS $\alpha \beta$ proteins (DeSamblanx et al., 1997; Cohen et al., 2009). Non-morphogenic proteins contain polar residues in this interstrand loop, while morphogenic ones exhibit a hydrophobic cluster at the protein surface in which a lysine residue is embedded (Cohen et al., 2009). Cohen et al. proposed that the antifungal active site of drosomycin is formed by the hydrophobic cluster Leu3, Pro10, Pro35, Leu37 and Trp40 where the basic residue Lys38 is embedded (Cohen et al., 2009). On Ts1, these residues correspond to Asp7, Ser14, Ala38, Pro40, Tyr43 and Ala41. These differences could justify why Ts1 does not alter the morphology of the treated hyphae. Additionally, we can conclude that Ts1 causes no interference at morphogenetic $\mathrm{Ca}^{2+}$ signaling, since the branching of fungal hyphae is regulated by specific $\mathrm{Ca}^{2+}$ channels (Robson et al., 1991).

In respect to electrostatic interactions, drosomycin caused partial lysis of the growing hyphae of Botrytis cinerea in halfstrength potato dextrose broth supplemented with $1 \mathrm{mM} \mathrm{CaCl}$ and $20 \mathrm{mM} \mathrm{KCl} \mathrm{(Fehlbaum} \mathrm{et} \mathrm{al.,} \mathrm{1994).} \mathrm{Monovalent} \mathrm{and}$ especially divalent cations in the medium play an antagonizing effect on defensins' antimicrobial activity (for review, see Aerts et al., 2008). This antagonistic effect depends on the tested fungus, indicating that electrostatic interactions on the fungal membrane are relevant for the antifungal activity (Broekaert et al., 1995). As previously mentioned, the addition of $\mathrm{CaCl}_{2}$ potentiated the inhibitory effect of Ts1, reinforcing that Ts1 may present a possible new antifungal mode-of-action.

By virtue of the increasing antimycotic drug resistance, the discovery of new mechanisms of action with greater antifungal specificity can lead to a potential therapeutic innovation.

\section{CONCLUSION}

Tityus serrulatus venom, its fractions IX, X, XI, XIIA, XIIB and its major toxin Ts1 inhibited fungi growth. Ts1 is a voltage-gated $\mathrm{Na}^{+}$channel toxin that may be performing a striking antifungal mode-of-action, since voltage-gated $\mathrm{Na}^{+}$channels have not been reported in fungi. Further studies to enlighten its mechanism of action on fungi are necessary. Ts1 is a multifunctional toxin

\section{REFERENCES}

Aerts, A. M., Francois, I., Cammue, B. P. A., and Thevissen, K. (2008). The mode of antifungal action of plant, insect and human defensins. Cell Mol. Life Sci. 65, 2069-2079. doi: 10.1007/s00018-008-8035-0

Almaaytah, A., Tarazi, S., Abu-Alhaijaa, A., Altall, Y., Alshar'i, N., Bodoor, K., et al. (2014). Enhanced antimicrobial activity of AamAP1-Lysine, a novel synthetic peptide analog derived from the scorpion venom peptide AamAP1. Pharmaceuticals 7, 502-516. doi: 10.3390/ph7050502

Arantes, E. C., Prado, W. A., Sampaio, S. V., and Giglio, J. R. (1989). A simplified procedure for the fractionation of Tityus serrulatus venom - isolation and partial characterization of TsTX-IV, a new neurotoxin. Toxicon 27, 907-916. doi: 10.1016/0041-0101(89)90102-5

Ayroza, G., Ferreira, I. L. C., Sayegh, R. S. R., Tashima, A. K., and da Silva, P. I. (2012). Juruin: an antifungal peptide from the venom of the Amazonian Pink which may be a relevant research tool in the design of engineered scorpion AMPs and in the search for new mechanisms of action of antifungal drugs.

\section{AUTHOR CONTRIBUTIONS}

WS and ARA carried out all the experiments. CC helped in drafting the manuscript. KB performed the structural alignment and drafted the manuscript. SS participated in the design of the antifungal assays. EA is the corresponding author and designer of the research. WS and KB contributed equally to this work. All authors analyzed the results, revised the manuscript and approved the final version.

\section{FUNDING}

This study was supported by the Fundação de Amparo à Pesquisa do Estado de São Paulo (FAPESP, São Paulo Research Foundation, grants n. 05/54855-0 and n. 2015/18432-0; scholarship to WS n. 05/56592-7), Conselho Nacional de Desenvolvimento Científico e Tecnológico (CNPq, The National Council for Scientific and Technological Development, scholarship to ARA n. 115948/2007-4), and Coordenação de Aperfeiçoamento de Pessoal de Nivel Superior (CAPES, Coordination for the Improvement of Higher Education Personnel).

\section{ACKNOWLEDGMENTS}

The authors acknowledge Daniela Trinca Bertazzi, Flávia Pine Leite, and Maria Angélica dos Santos Cunha Chellegatti for their helpful technical support. We are indebted to Dr. Sérgio de Albuquerque, FCFRP-USP, for the provision of some laboratory facilities.

\section{SUPPLEMENTARY MATERIAL}

The Supplementary Material for this article can be found online at: http://journal.frontiersin.org/article/10.3389/fmicb. 2017.00984/full\#supplementary-material

Toe spider, Avicularia juruensis, which contains the inhibitory cystine knot motif. Front. Microbiol. 3:324. doi: 10.3389/fmicb.2012.00324

Baddley, J. W., Pappas, P. G., Smith, A. C., and Moser, S. A. (2003). Epidemiology of Aspergillus terreus at a university hospital. J. Clin. Microbiol. 41, 5525-5529. doi: 10.1128/JCM.41.12.5525-5529.2003

Bane, V., Lehane, M., Dikshit, M., O’Riordan, A., and Furey, A. (2014). Tetrodotoxin: chemistry, toxicity, source, distribution and detection. Toxins 6, 693-755. doi: 10.3390/toxins6020693

Becerril, B., Marangoni, S., and Possani, L. D. (1997). Toxins and genes isolated from scorpions of the genus Tityus. Toxicon 35, 821-835. doi: 10.1016/S00410101(96)00198-5

Bordon, K. C. F., Cologna, C. T., Arantes, E. C., and de la Vega, R. C. R. (2015). "Scorpion venom research around the world: Tityus serrulatus", in Scorpion Venoms, eds P. Gopalakrishnakone, L. D. Possani, and E. F. Schwartz (Dordrecht: Springer), 411-438. 
Brakhage, A. A. (2005). Systemic fungal infections caused by Aspergillus species: epidemiology, infection process and virulence determinants. Curr. Drug Targets 6, 875-886. doi: 10.2174/138945005774912717

Broekaert, W. F., Terras, F. R. G., Cammue, B. P. A., and Osborn, R. W. (1995). Plant defensins: novel antimicrobial peptides as components of the host defense system. Plant Physiol. 108, 1353-1358. doi: 10.1104/pp.108.4.1353

Broekaert, W. F., Terras, F. R. G., Cammue, B. P. A., and Vanderleyden, J. (1990). An automated quantitative assay for fungal growth-inhibition. FEMS Microbiol. Lett. 69, 55-59. doi: 10.1111/j.1574-6968.1990.tb04174.x

Bulet, P., Hetru, C., Dimarcq, J. L., and Hoffmann, D. (1999). Antimicrobial peptides in insects; structure and function. Dev. Comp. Immunol. 23, 329-344. doi: 10.1016/S0145-305X(99)00015-4

Bulet, P., Stocklin, R., and Menin, L. (2004). Anti-microbial peptides: from invertebrates to vertebrates. Immunol. Rev. 198, 169-184. doi: 10.1111/j.01052896.2004.0124.x

Cabezas-Quintario, M. A., Guerrero, C., Gomez, P., and Perez-Fernandez, E. (2016). Prevalence of invasive fungal infections detected at necropsy in a medium-sized hospital: a 15-year review of autopsy findings. Rev. Esp. Patol. 49, 76-80. doi: 10.1016/j.patol.2016.01.007

Cociancich, S., Ghazi, A., Hetru, C., Hoffmann, J. A., and Letellier, L. (1993). Insect defensin, an inducible antibacterial peptide, forms voltage-dependent channels in Micrococcus luteus. J. Biol. Chem. 268, 19239-19245.

Cohen, L., Moran, Y., Sharon, A., Segal, D., Gordon, D., and Gurevitz, M. (2009). Drosomycin, an innate immunity peptide of Drosophila melanogaster, interacts with the fly voltage-gated sodium channel. J. Biol. Chem. 284, 23558-23563. doi: 10.1074/jbc.M109.023358

Cologna, C. T., Marcussi, S., Giglio, J. R., Soares, A. M., and Arantes, E. C. (2009). Tityus serrulatus scorpion venom and toxins: an overview. Protein Pept. Lett. 16, 920-932. doi: 10.2174/092986609788923329

Conde, R., Zamudio, F. Z., Rodriguez, M. H., and Possani, L. D. (2000). Scorpine, an anti-malaria and anti-bacterial agent purified from scorpion venom. FEBS Lett. 471, 165-168. doi: 10.1016/S0014-5793(00)01384-3

Corzo, G., Escoubas, P., Villegas, E., Barnham, K. J., He, W. L., Norton, R. S., et al. (2001). Characterization of unique amphipathic antimicrobial peptides from venom of the scorpion Pandinus imperator. Biochem. J. 359, 35-45. doi: $10.1042 / b j 3590035$

DeLano, W. L. (2002). PyMOL: an open-source molecular graphics tool. CCP4 Newsl. Protein Crystallogr. 40, 82-92.

DeSamblanx, G. W., Goderis, I. J., Thevissen, K., Raemaekers, R., Fant, F., Borremans, F., et al. (1997). Mutational analysis of a plant defensin from radish (Raphanus sativus $\mathrm{L}$ ) reveals two adjacent sites important for antifungal activity. J. Biol. Chem. 272, 1171-1179. doi: 10.1074/jbc.272.2.1171

Diaz, P., D’Suze, G., Salazar, V., Sevcik, C., Shannon, J. D., Sherman, N. E., et al. (2009). Antibacterial activity of six novel peptides from Tityus discrepans scorpion venom. A fluorescent probe study of microbial membrane $\mathrm{Na}^{+}$ permeability changes. Toxicon 54, 802-817. doi: 10.1016/j.toxicon.2009.06.014

Diego-Garcia, E., Abdel-Mottaleb, Y., Schwartz, E. F., de la Vega, R. C., Tytgat, J., and Possani, L. D. (2008). Cytolytic and $\mathrm{K}^{+}$channel blocking activities of betaKTx and scorpine-like peptides purified from scorpion venoms. Cell Mol. Life Sci. 65, 187-200. doi: 10.1007/s00018-007-7370-x

Du, Q., Hou, X. J., Ge, L. L., Li, R. J., Zhou, M., Wang, H., et al. (2014). Cationicityenhanced analogues of the antimicrobial peptides, AcrAP1 and AcrAP2, from the venom of the scorpion, Androctonus crassicauda, display potent growth modulation effects on human cancer cell lines. Int. J. Biol. Sci. 10, 1097-1107. doi: $10.7150 /$ ijbs. 9859

Du, Q., Hou, X. J., Wang, L., Zhang, Y. Q., Xi, X. P., Wang, H., et al. (2015). AaeAP1 and AaeAP2: novel antimicrobial peptides from the venom of the scorpion, Androctonus aeneas: structural characterisation, molecular cloning of biosynthetic precursor-encoding cDNAs and engineering of analogues with enhanced antimicrobial and anticancer activities. Toxins 7, 219-237. doi: 10.3390/toxins7020219

Eastwood, M. P., Hardin, C., Luthey-Schulten, Z., and Wolynes, P. G. (2001). Evaluating protein structure-prediction schemes using energy landscape theory. IBM J. Res. Dev. 45, 475-497. doi: 10.1147/rd.453.0475

Elias, B. C., Said, S., de Albuquerque, S., and Pupo, M. T. (2006). The influence of culture conditions on the biosynthesis of secondary metabolites by Penicillium verrucosum Dierck. Microbiol. Res. 161, 273-280. doi: 10.1016/j.micres.2005. 10.003
Fehlbaum, P., Bulet, P., Michaut, L., Lagueux, M., Broekaert, W. F., Hetru, C., et al. (1994). Insect immunity - septic injury of Drosophila induces the synthesis of a potent antifungal peptide with sequence homology to plant antifungal peptides. J. Biol. Chem. 269, 33159-33163.

Feng, J., Yu, C. Y., Wang, M. Y., Li, Z., Wu, Y. L., Cao, Z. J., et al. (2013). Expression and characterization of a novel scorpine-like peptide Ev37, from the scorpion Euscorpiops validus. Protein Expr. Purif. 88, 127-133. doi: 10.1016/j.pep.2012. 12.004

Freitas, T. P. S., Furtado, N., Bastos, J. K., and Said, S. (2002). Active substances against trypomastigote forms of Trypanosoma cruzi and microorganisms are produced in sequence by Talaromyces flavus. Microbiol. Res. 2002, 201-206. doi: 10.1078/0944-5013-00148

Gao, B., and Zhu, S. Y. (2008). Differential potency of drosomycin to Neurospora crassa and its mutant: implications for evolutionary relationship between defensins from insects and plants. Insect Mol. Biol. 17, 405-411. doi: 10.1111/ j.1365-2583.2008.00810.x

Ghezzi, A., Liebeskind, B. J., Thompson, A., Atkinson, N. S., and Zakon, H. H. (2014). Ancient association between cation leak channels and Midi proteins is conserved in fungi and animals. Front. Mol. Neurosci. 7:15. doi: 10.3389/fnmol. 2014.00015

Gozlan, R. E., Marshall, W. L., Lilje, O., Jessop, C. N., Gleason, F. H., and Andreou, D. (2014). Current ecological understanding of fungal-like pathogens of fish: What lies beneath? Front. Microbiol. 5:62. doi: 10.3389/fmicb.2014.00062

Guilhelmelli, F., Vilela, N., Smidt, K. S., de Oliveira, M. A., Alvares, A. D. M., Rigonatto, M. C. L., et al. (2016). Activity of scorpion venom-derived antifungal peptides against planktonic cells of Candida spp. and Cryptococcus neoformans and Candida albicans biofilms. Front. Microbiol. 7:1844. doi: 10.3389/fmicb. 2016.01844

Harrison, P. L., Abdel-Rahman, M. A., Miller, K., and Strong, P. N. (2014). Antimicrobial peptides from scorpion venoms. Toxicon 88, 115-137. doi: 10.1016/j.toxicon.2014.06.006

Harrison, P. L., Abdel-Rahman, M. A., Strong, P. N., Tawfik, M. M., and Miller, K. (2016). Characterisation of three alpha-helical antimicrobial peptides from the venom of Scorpio maurus palmatus. Toxicon 117, 30-36. doi: 10.1016/j.toxicon. 2016.03.014

Hegedus, N., and Marx, F. (2013). Antifungal proteins: More than antimicrobials? Fungal Biol. Rev. 26, 132-145.

Hoffmann, L., and Mayer, M. (1977). "Immune hemolysis and complement fixation," in Methods in Immunology and Immunochemistry, eds C. A. Williams and M. W. Chase (New York, NY: Academic Press), 137-166.

Humphrey, W., Dalke, A., and Schulten, K. (1996). VMD: visual molecular dynamics. J. Mol. Graph. 14, 33-38. doi: 10.1016/0263-7855(96)00018-5

Jenssen, H., Hamill, P., and Hancock, R. E. W. (2006). Peptide antimicrobial agents. Clin. Microbiol. Rev. 19, 491-511. doi: 10.1128/CMR.00056-05

Joya, G., D’Suze, G., Salazar, V., Rosales, A., Sevcik, C., Visbal, G., et al. (2011). Scorpion toxins modify phytopathogenic fungus physiology. A possible source of new fungicides. J. Agric. Food Chem. 59, 6327-6337. doi: 10.1021/jf200486t

Kniemeyer, O. (2011). Proteomics of eukaryotic microorganisms: the medically and biotechnologically important fungal genus Aspergillus. Proteomics 11, 3232-3243. doi: 10.1002/pmic.201100087

Kuhn-Nentwig, L., Schaller, J., and Nentwig, W. (2004). Biochemistry, toxicology and ecology of the venom of the spider Cupiennius salei (Ctenidae). Toxicon 43, 543-553. doi: 10.1016/j.toxicon.2004.02.009

Landon, C., Sodano, P., Hetru, C., Hoffmann, J., and Ptak, M. (1997). Solution structure of drosomycin, the first inducible antifungal protein from insects. Protein Sci. 6, 1878-1884. doi: 10.1002/pro.5560060908

Lehrer, R. I., Ganz, T., Szklarek, D., and Selsted, M. E. (1988). Modulation of the in vitro candidacidal activity of human neutrophil defensins by target cell metabolism and divalent cations. J. Clin. Invest. 81, 1829-1835. doi: 10.1172/ JCI113527

Lewis, R. J., and Garcia, M. L. (2003). Therapeutic potential of venom peptides. Nat. Rev. Drug Discov. 2, 790-802. doi: 10.1038/nrd1197

Liebeskind, B. J., Hillis, D. M., and Zakon, H. H. (2012). Phylogeny unites animal sodium leak channels with fungal calcium channels in an ancient, voltageinsensitive clade. Mol. Biol. Evol. 29, 3613-3616. doi: 10.1093/molbev/mss182

Little, C., and Rumsby, M. G. (1980). Lysis of erythrocytes from stored human blood by phospholipase C (Bacillus cereus). Biochem. J. 1980, 39-46. doi: $10.1042 / b j 1880039$ 
Lowe, R. M., and Farrell, P. M. (2011). A portable device for the electrical extraction of scorpion venom. Toxicon 57, 244-247. doi: 10.1016/j.toxicon.2010.11.017

Luke, A. K., and Burton, S. G. (2001). A novel application for Neurospora crassa: progress from batch culture to a membrane bioreactor for the bioremediation of phenols. Enzyme Microb. Technol. 29, 348-356. doi: 10.1016/S0141-0229(01) 00390-8

Luna-Ramirez, K., Quintero-Hernandez, V., Vargas-Jaimes, L., Batista, C. V. F., Winkel, K. D., and Possani, L. D. (2013). Characterization of the venom from the Australian scorpion Urodacus yaschenkoi: molecular mass analysis of components, cDNA sequences and peptides with antimicrobial activity. Toxicon 63, 44-54. doi: 10.1016/j.toxicon.2012.11.017

Luna-Ramirez, K., Tonk, M., Rahnamaeian, M., and Vilcinskas, A. (2017). Bioactivity of natural and engineered antimicrobial peptides from venom of the scorpions Urodacus yaschenkoi and U. manicatus. Toxins 9:22. doi: 10.3390/ toxins 9010022

Michaut, L., Fehlbaum, P., Moniatte, M., VanDorsselaer, A., Reichhart, J. M., and Bulet, P. (1996). Determination of the disulfide array of the first inducible antifungal peptide from insects: drosomycin from Drosophila melanogaster. FEBS Lett. 395, 6-10. doi: 10.1016/0014-5793(96)00992-1

Mookherjee, N., and Hancock, R. E. W. (2007). Cationic host defence peptides: innate immune regulatory peptides as a novel approach for treating infections. Cell Mol. Life Sci. 64, 922-933. doi: 10.1007/s00018-007-6475-6

Narahashi, T., Moore, J. W., and Scott, W. R. (1964). Tetrodotoxin blockage of sodium conductance increase in lobster giant axons. J. Gen. Physiol. 47, 965-974. doi: 10.1085/jgp.47.5.965

Ortiz, E., Gurrola, G. B., Schwartz, E. F., and Possani, L. D. (2015). Scorpion venom components as potential candidates for drug development. Toxicon 93, 125-135. doi: 10.1016/j.toxicon.2014.11.233

Osborn, R. W., Desamblanx, G. W., Thevissen, K., Goderis, I., Torrekens, S., Vanleuven, F., et al. (1995). Isolation and characterisation of plant defensins from seeds of Asteraceae, Fabaceae, Hippocastanaceae and Saxifragaceae. FEBS Lett. 368, 257-262. doi: 10.1016/0014-5793(95)00666-W

Pedron, C. N., Torres, M. T., Lima, J. A., Silva, P. I., Silva, F. D., and Oliveira, V. X. (2017). Novel designed VmCT1 analogs with increased antimicrobial activity. Eur. J. Med. Chem. 126, 456-463. doi: 10.1016/j.ejmech.2016.11.040

Peigneur, S., Cologna, C. T., Cremonez, C. M., Mille, B. G., Pucca, M. B., Cuypers, E., et al. (2015). A gamut of undiscovered electrophysiological effects produced by Tityus serrulatus toxin 1 on NaV-type isoforms. Neuropharmacology 95, 269-277. doi: 10.1016/j.neuropharm.2015.03.027

Peigneur, S., Sevcik, C., Tytgat, J., Castillo, C., and D’Suze, G. (2012). Subtype specificity interaction of bactridines with mammalian, insect and bacterial sodium channels under voltage clamp conditions. FEBS J. 279, 4025-4038. doi: 10.1111/j.1742-4658.2012.08808.x

Petricevich, V. L., Cruz, A. H., Coronas, F. I. V., and Possani, L. D. (2007). Toxin gamma from Tityus serrulatus scorpion venom plays an essential role in immunomodulation of macrophages. Toxicon 50, 666-675. doi: 10.1016/j. toxicon.2007.06.001

Pimenta, A. M. C., and De Lima, M. E. (2005). Small peptides, big world: biotechnological potential in neglected bioactive peptides from arthropod venoms. J. Pept. Sci. 11, 670-676. doi: 10.1002/psc.701

Pinheiro, C. B., Marangoni, S., Toyama, M. H., and Polikarpov, I. (2003). Structural analysis of Tityus serrulatus Ts1 neurotoxin at atomic resolution: insights into interactions with $\mathrm{Na}^{+}$channels. Acta Crystallogr. Sect. D Biol. Crystallogr. 59, 405-415. doi: 10.1107/S090744490202111X

Polikarpov, I., Matilde, M. S., Marangoni, S., Toyama, M. H., and Teplyakov, A. (1999). Crystal structure of neurotoxin Ts1 from Tityus serrulatus provides insights into the specificity and toxicity of scorpion toxins. J. Mol. Biol. 290, 175-184. doi: 10.1006/jmbi.1999.2868

Pontecorvo, G., Roper, J. A., Hemmons, L. M., Macdonald, K. D., and Bufton, A. W. J. (1953). The genetics of Aspergillus nidulans. Adv. Genet. 5, 141-238. doi: 10.1016/s0065-2660(08)60408-3

Possani, L. D., Alagon, A. C., Fletcher, P. L., and Erickson, B. W. (1977). Purification and properties of mammalian toxins from the venom of brazilian scorpion Tityus serrulatus Lutz and Mello. Arch. Biochem. Biophys. 180, 394-403. doi: 10.1016/0003-9861(77)90053-4

Prole, D. L., and Taylor, C. W. (2012). Identification and analysis of cation channel homologues in human pathogenic fungi. PLOS ONE 7:e42404. doi: 10.1371/ journal.pone.0042404
Pucca, M. B., Amorim, F. G., Cerni, F. A., Bordon Ke, C., Cardoso, I. A., Anjolette, F. A., et al. (2014). Influence of post-starvation extraction time and prey-specific diet in Tityus serrulatus scorpion venom composition and hyaluronidase activity. Toxicon 90, 326-336. doi: 10.1016/j.toxicon.2014.08.064

Reisfeld, R. A., Lewis, U. J., and Williams, D. E. (1962). Disk electrophoresis of basic proteins and peptides on polyacrylamide gels. Nature 195, 281-283. doi: 10.1038/195281a0

Remijsen, Q., Verdonck, F., and Willems, J. (2010). Parabutoporin, a cationic amphipathic peptide from scorpion venom: much more than an antibiotic. Toxicon 55, 180-185. doi: 10.1016/j.toxicon.2009.10.027

Roberts, E., Eargle, J., Wright, D., and Luthey-Schulten, Z. (2006). MultiSeq: unifying sequence and structure data for evolutionary analysis. $B M C$ Bioinformatics 7:382. doi: 10.1186/1471-2105-7-382

Robson, G. D., Wiebe, M. G., and Trinci, A. P. J. (1991). Involvement of $\mathrm{Ca}^{2+}$ in the regulation of hyphal extension and branching in Fusarium graminearum A 3/5. Exp. Mycol. 15, 263-272. doi: 10.1016/0147-5975(91)90028-C

Rodríguez de la Vega, R. C., and Possani, L. D. (2004). Current views on scorpion toxins specific for K+-channels. Toxicon 43, 865-875. doi: 10.1016/j.toxicon. 2004.03.022

Rodríguez de la Vega, R. C., and Possani, L. D. (2005). Overview of scorpion toxins specific for $\mathrm{Na}^{+}$channels and related peptides: biodiversity, structure-function relationships and evolution. Toxicon 46, 831-844. doi: 10.1016/j.toxicon.2005. 09.006

Schwartz, E. F., Camargos, T. S., Zamudio, F. Z., Silva, L. P., Bloch, C., Caixeta, F., et al. (2008). Mass spectrometry analysis, amino acid sequence and biological activity of venom components from the Brazilian scorpion Opisthacanthus cayaporum. Toxicon 51, 1499-1508. doi: 10.1016/j.toxicon.2008.03.029

Scopes, R. K. (1974). Measurement of protein by spectrophotometry at $205 \mathrm{~nm}$. Anal. Biochem. 59, 277-282. doi: 10.1016/0003-2697(74)90034-7

Senatore, A., Monteil, A., van Minnen, J., Smit, A. B., and Spafford, J. D. (2013). NALCN ion channels have alternative selectivity filters resembling calcium channels or sodium channels. PLoS ONE 8:e55088. doi: 10.1371/journal.pone. 0055088

Seneviratne, C. J., and Rosa, E. A. R. (2016). Editorial: antifungal drug discovery: new theories and new therapies. Front. Microbiol. 7:728. doi: 10.3389/fmicb. 2016.00728

Sievers, F., Wilm, A., Dineen, D., Gibson, T. J., Karplus, K., Li, W. Z., et al. (2011). Fast, scalable generation of high-quality protein multiple sequence alignments using Clustal Omega. Mol. Syst. Biol. 7:539. doi: 10.1038/msb.2011.75

Stephenson, J. (1997). Investigators seeking new ways to stem rising tide of resistant fungi. JAMA 277, 5-6. doi: 10.1001/jama.1997.03540250013006

Terras, F. R. G., Schoofs, H. M. E., Debolle, M. F. C., Vanleuven, F., Rees, S. B., Vanderleyden, J., et al. (1992). Analysis of two novel classes of plant antifungal proteins from radish (Raphanus sativus L.) seeds. J. Biol. Chem. 267, 15301-15309.

Tortorano, A. M., Dho, G., Prigitano, A., Breda, G., Grancini, A., Emmi, V., et al. (2012). Invasive fungal infections in the intensive care unit: a multicentre, prospective, observational study in Italy (2006-2008). Mycoses 55, 73-79. doi: 10.1111/j.1439-0507.2011.02044.x

Tytgat, J., Chandy, K. G., Garcia, M. L., Gutman, G. A., Martin-Eauclaire, M. F., van der Walt, J. J., et al. (1999). A unified nomenclature for short-chain peptides isolated from scorpion venoms: alpha-KTx molecular subfamilies. Trends Pharmacol. Sci. 20, 444-447. doi: 10.1016/S0165-6147(99) 01398-X

Uawonggul, N., Thammasirirak, S., Chaveerach, A., Arkaravichien, T., Bunyatratchata, W., Ruangjirachuporn, W., et al. (2007). Purification and characterization of Heteroscorpine-1 (HS-1) toxin from Heterometrus laoticus scorpion venom. Toxicon 49, 19-29. doi: 10.1016/j.toxicon.2006.09.003

Vasconcelos, F., Lanchote, V. L., Bendhack, L. M., Giglio, J. R., Sampaio, S. V., and Arantes, E. C. (2005). Effects of voltage-gated $\mathrm{Na}^{+}$channel toxins from Tityus serrulatus venom on rat arterial blood pressure and plasma catecholamines. Comp. Biochem. Physiol. C Toxicol. Pharmacol. 141, 85-92.

Vincent, J. L., Rello, J., Marshall, J., Silva, E., Anzueto, A., Martin, C. D., et al. (2009). International study of the prevalence and outcomes of infection in intensive care units. JAMA 302, 2323-2329. doi: 10.1001/jama.2009.1754

Wilmes, M., Cammue, B. P. A., Sahl, H. G., and Thevissen, K. (2011). Antibiotic activities of host defense peptides: more to it than lipid bilayer perturbation. Nat. Prod. Rep. 28, 1350-1358. doi: 10.1039/c1np00022e 
Zasloff, M. (2002). Antimicrobial peptides of multicellular organisms. Nature 415, 389-395. doi: 10.1038/415389a

Zhang, Y., and Skolnick, J. (2005). TM-align: a protein structure alignment algorithm based on the TM-score. Nucleic Acids Res. 33, 2302-2309. doi: 10.1093/nar/gki524

Zhu, S., and Tytgat, J. (2004). The scorpine family of defensins: gene structure, alternative polyadenylation and fold recognition. Cell Mol. Life Sci. 61, 1751-1763. doi: 10.1007/s00018-004-4149-1

Zhu, S. Y., Peigneur, S., Gao, B., Umetsu, Y., Ohki, S., and Tytgat, J. (2014). Experimental conversion of a defensin into a neurotoxin: implications for origin of toxic function. Mol. Biol. Evol. 31, 546-559. doi: 10.1093/molbev/ msu038

Zoccal, K. F., Bitencourt, C. S., Paula-Silva, F. W. G., Sorgi, C. A., Bordon, K. C. F., Arantes, E. C., et al. (2014). TLR2, TLR4 and CD14 recognize venomassociated molecular patterns from Tityus serrulatus to induce macrophagederived inflammatory mediators. PLOS ONE 9:e88174. doi: 10.1371/journal. pone. 0088174
Zoccal, K. F., Bitencourt, C. S., Secatto, A., Sorgi, C. A., Bordon, K. C. F., Sampaio, S. V., et al. (2011). Tityus serrulatus venom and toxins Ts1, Ts2 and Ts6 induce macrophage activation and production of immune mediators. Toxicon 57, 1101-1108. doi: 10.1016/j.toxicon.2011. 04.017

Conflict of Interest Statement: The authors declare that the research was conducted in the absence of any commercial or financial relationships that could be construed as a potential conflict of interest.

Copyright (C) 2017 Santussi, Bordon, Rodrigues Alves, Cologna, Said and Arantes. This is an open-access article distributed under the terms of the Creative Commons Attribution License (CC BY). The use, distribution or reproduction in other forums is permitted, provided the original author(s) or licensor are credited and that the original publication in this journal is cited, in accordance with accepted academic practice. No use, distribution or reproduction is permitted which does not comply with these terms. 